\title{
The inositol 1,4,5-trisphosphate receptor regulates autophagy through its interaction with Beclin 1
}

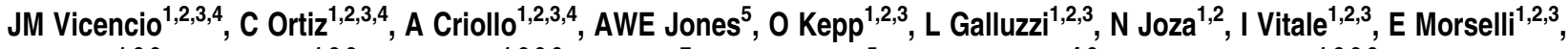

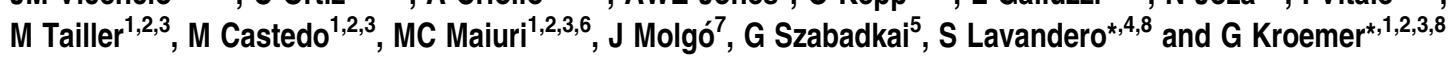

The inositol 1,4,5-trisphosphate receptor $\left(\mathrm{IP}_{3} \mathrm{R}\right)$ is a major regulator of apoptotic signaling. Through interactions with members of the Bcl-2 family of proteins, it drives calcium $\left(\mathrm{Ca}^{2+}\right)$ transients from the endoplasmic reticulum (ER) to mitochondria, thereby establishing a functional and physical link between these organelles. Importantly, the $I_{3} R$ also regulates autophagy, and in particular, its inhibition/depletion strongly induces macroautophagy. Here, we show that the $I_{3} R$ antagonist xestospongin $B$ induces autophagy by disrupting a molecular complex formed by the $I_{3} R$ and Beclin 1 , an interaction that is increased or inhibited by overexpression or knockdown of Bcl-2, respectively. An effect of Beclin 1 on $\mathrm{Ca}^{2+}$ homeostasis was discarded as siRNA-mediated knockdown of Beclin 1 did not affect cytosolic or luminal ER $\mathrm{Ca}^{2+}$ levels. Xestospongin $\mathrm{B}$ - or starvationinduced autophagy was inhibited by overexpression of the $\mathbb{I P}_{3} R$ ligand-binding domain, which coimmunoprecipitated with Beclin 1. These results identify $I P_{3} R$ as a new regulator of the Beclin 1 complex that may bridge signals converging on the ER and initial phagophore formation.

Cell Death and Differentiation (2009) 16, 1006-1017; doi:10.1038/cdd.2009.34; published online 27 March 2009

Macroautophagy (herein referred to as autophagy) is the major catabolic pathway for entire organelles, long-lived/ aberrant proteins and superfluous portions of the cytosol. It consists of the stepwise engulfment of substrate elements into distinctive multimembraned autophagosomes, which after fusion with lysosomes form single-membraned autolysosomes. Within the lumen of autolysosomes, macromolecules are enzymatically broken down into metabolites that cope with the bioenergetic and biosynthetic demands of the cell. ${ }^{1,2}$

The molecular activation of autophagy is a complex process (reviewed in Yorimitsu and Klionsky ${ }^{3}$ ) that is regulated by the mammalian target of rapamycin (mTOR), a protein kinase essential for nutrient-sensing signal transduction. ${ }^{4}$ Downstream of mTOR, a series of chain reactions are executed by several autophagy-related (Atg) proteins, allowing the preautophagosomal membrane structure (phagophore) to engulf a substrate material, to complete and close the sequestering vacuole in physical association with the microtubular network, and finally fuse autophagosomes with lysosomes to execute degradation. The autophagic functions of the phylogenetically conserved family of atg genes have extensively been studied in yeast. ${ }^{5,6}$ One of the most important members of this family is atg6, whose mammalian ortholog is represented by the haploinsufficient tumor suppressor gene beclin $1^{7,8}$ In mammalian cells, Beclin 1 acts concertedly with Vps34, Vps15, UVRAG, Bif1, Ambra1 and perhaps other proteins to form a multiprotein complex with class III phosphatidylinositol 3-kinase (PI3K) activity that generates phosphatidylinositol-3phosphate (PI3P). PI3P determines the curvature of the nascent phagophore and promotes the recruitment of other Atg proteins (including Atg5, Atg12, Atg10, Atg4, Atg3, Atg7, Atg8 and Atg16), which catalyze vesicle elongation and phagophore nucleation. ${ }^{6,9}$

Although classically viewed as an essential mechanism of adaptation to stress, in particular to that imposed by the lack of nutrients, excessive or inefficient autophagy may be involved in autophagic cell death (ACD). ${ }^{9-11}$ At a molecular level, the cross-talk between apoptosis and autophagy is beginning to be understood, and some factors have recently been identified as common regulators of both pathways. ${ }^{9,12,13}$ For

\footnotetext{
${ }^{1}$ INSERM, U848, F-94805 Villejuif, France; ${ }^{2}$ Institut Gustave Roussy, F-94805 Villejuif, France; ${ }^{3}$ Université Paris 11, F-94805 Villejuif, France; ${ }^{4}$ Faculty of Chemical and Pharmaceutical Sciences/Medicine, FONDAP Center CEMC, University of Chile, CL-8380492 Santiago, Chile; ${ }^{5}$ Mitochondrial Biology Group, Department of Cell and Developmental Biology, University College London, London, WC1E 6BT, UK; ${ }^{6}$ Facoltá di Scienze Biotecnologiche, Universitá degli Studi di Napoli Federico II, I-80131 Napoli, Italy and ${ }^{7}$ Centre National de la Recherche Scientifique, Institut de Neurobiologie Alfred Fessard, FRC2118, UPR 9040, F-91198 Gif-sur-Yvette, France *Corresponding authors: G Kroemer, INSERM U848, Institut Gustave Roussy, 39 rue Camille Desmoulins, 94805 Villejuif, France. Tel:+33 142116046 ; Fax:+33 1421160 47; E-mail: kroemer@igr.fr or S Lavandero, FONDAP Center CEMC, Faculty of Chemical and Pharmaceutical Sciences, University of Chile, Olivos 1007, 8380492 Santiago, Chile. E-mail: slavander@uchile.cl

${ }^{8}$ These authors share senior co-autorship.

Keywords: apoptosis; Atg genes; autophagic cell death; LC3; lysosomes

Abbreviations: ACD, autophagic cell death; Ambra, activating molecule in Beclin 1-regulated autophagy; Atg, autophagy-related gene; $\mathrm{Ca}^{2+}, \mathrm{calcium}^{2}\left[\mathrm{Ca}^{2+}\right], \mathrm{Ca}^{2+}$ concentration; $\left[\mathrm{Ca}^{2+}\right]_{c}$, cytosolic [ $\left.\mathrm{Ca}^{2+}\right]$; CFP, cyan fluorescent protein; cytAEQ, cytosolic aequorin; Cyto, cytosolic; ER, endoplasmic reticulum; FBS, fetal bovine serum; FRET, fluorescence resonance energy transfer; GFP, green fluorescent protein; GFP-LC3, GFP-coupled microtubule-associated protein light chain 3; IMP, inositol monophosphatase ; $\mathrm{IP}_{3}$, myo-inositol 1,4,5-trisphosphate; $\mathrm{IP}_{3} \mathrm{R}, \mathrm{IP}_{3}$ receptor; LBD, ligand-binding domain; mTOR, mammalian target of rapamycin; OMM, outer mitochondrial membrane; PI3K, phosphatidylinositol 3-kinase; PI3P, phosphatidylinositol-3-phosphate; RFP, red fluorescent protein; SERCA, sarco-endoplasmic reticulum $\mathrm{Ca}^{2+}$ ATPase; tBHQ, 2,5-di(ter-butyl)-1,4 benzohydroquinone; UVRAG, UV irradiation resistance-associated tumor suppressor gene; Vps, vacuolar protein sorting; YFP, yellow fluorescent protein

Received 14.7.08; revised 25.2.09; accepted 25.2.09; Edited by D Rubinsztein; published online 27.3.09
} 
instance, the activity of Beclin 1 is inhibited by the antiapoptotic proteins $\mathrm{Bcl}-2$ and $\mathrm{Bcl}-\mathrm{X}_{\mathrm{L}}$ due to the interaction between the $\mathrm{BH} 3$ domain present in Beclin 1 and the $\mathrm{BH}$ receptor cleft of $\mathrm{Bcl}-2 / \mathrm{X}_{\mathrm{L}}$. This binding is competitively disrupted by proapoptotic $\mathrm{BH}$ 3-only proteins, which therefore can promote autophagy. ${ }^{14-16}$

Autophagy can also be induced through an mTORindependent pathway by lowering myo-inositol 1,4,5-trisphosphate $\left(\mathrm{IP}_{3}\right)$ levels. ${ }^{17}$ This effect can be achieved pharmacologically with drugs such as lithium or L-690 330, which disrupt inositol metabolism by inhibiting inositol monophosphatase (IMP). ${ }^{18} \mathrm{As} \mathrm{IP}_{3}$ is a second messenger that mediates $\mathrm{Ca}^{2+}$ release from the endoplasmic reticulum (ER), autophagy might also be regulated by $\mathrm{Ca}^{2+}$. This hypothesis has been addressed by a pioneering study, which concluded that $\mathrm{Ca}^{2+}$ fluxes are not necessary for autophagic stimulation and that autophagy would rather depend on the presence of $\mathrm{Ca}^{2+}$ within an intracellular storage compartment. ${ }^{19}$ Accordingly, cytosolic $\mathrm{Ca}^{2+}$ may even inhibit autophagy in a cyclical mTOR-independent pathway. ${ }^{18}$ Three recent studies have also explored the contribution of $\mathrm{Ca}^{2+}$ to autophagy, ${ }^{20-22}$ establishing that $\mathrm{Ca}^{2+}$ is required for autophagic induction, but showing some incongruities in whether increases in cytosolic $\left[\mathrm{Ca}^{2+}\right],{ }^{21,22}$ or modifications of ER $\mathrm{Ca}^{2+}$ levels, ${ }^{20}$ are responsible for the induction of autophagy. Irrespective of such discrepancies, all these studies showed that a Bcl-2 variant that is specifically targeted to the ER inhibits autophagy. 20,22

$\mathrm{Ca}^{2+}$ present in the ER lumen is released through specific channels. Two types of ER-resident $\mathrm{Ca}^{2+}$ release channels exist, namely the ryanodine receptors and the $\mathrm{IP}_{3}$ receptors $\left(I P_{3} R\right){ }^{23}$ Diverse physiological processes, including the mitochondrial (or intrinsic) pathway of apoptosis, are controlled by $\mathrm{Ca}^{2+}$ fluxes from the ER to mitochondria, which occur in the context of specific microdomains allowing for the functional and physical interaction between these organelles. ${ }^{24,25}$ The $I P_{3} R$ plays a critical role in this cross-talk and is currently considered as a major regulator of apoptotic signaling, which is also modulated by the members of the Bcl-2 family of proteins. ${ }^{24,26-28}$ The $\mathrm{IP}_{3} \mathrm{R}$ has also been shown to regulate autophagy. Indeed, its pharmacological inhibition with xestospongins and its depletion by specific siRNAs, represents a strong stimulus for the induction of autophagy, an effect that can be reverted by ER-targeted Bcl-2 overexpression. ${ }^{29,30}$ Moreover, it has been shown that the IP3R gene is required for the induction of ACD in Dyctiostelium discoideum. ${ }^{31,32}$

On the basis of these pieces of evidence, $\mathrm{IP}_{3} \mathrm{R}$ emerges as a possible key integrator of the cross-talk between apoptosis and autophagy. Here, we report that xestospongin B and nutrient starvation disrupt a molecular complex formed by the $I P_{3} R$, Beclin 1 and $B c l-2$, and present evidence that the $I_{3} R$ represses autophagy through $\mathrm{Bcl}-2$-mediated sequestration of Beclin 1.

\section{Results and Discussion}

Xestospongin $B$ induces autophagy by binding to the $\mathrm{IP}_{\mathbf{3}} \mathbf{R}$ in a $\mathbf{B c l - 2 - i n h i b i t a b l e}$ fashion. The natural compound xestospongin $B$ (purified from the marine sponge
Xestospongia exigua) is an $\mathrm{IP}_{3} \mathrm{R}$ antagonist that induces autophagy when added to a variety of animal cell lines, incuding human cervical adenocarcinoma HeLa cells (Figure 1a-d and Supplementary videos), Rat-1 fibroblasts (from Rattus norvegicus; data not shown) and DT40 B-cell lymphoma cells (from Gallus gallus; Figure 1d). This was assessed by determining the distribution of green fluorescent protein-coupled microtubule-associated protein light chain 3 (GFP-LC3) to cytoplasmic puncta (Figure 1a and b) or the lipidation of LC3, which leads to an increase in its electrophoretic mobility (from LC3-I to LC3-II; Figure 1C and d). Importantly, these effects were inhibited by overexpression of $\mathrm{Bcl}-2$ (Figure $1 \mathrm{a}-\mathrm{d}$ ) and were lost in DT40 cells depleted for all three $\mathrm{IP}_{3} \mathrm{R}$ isoforms through homologous recombination (Figure $1 \mathrm{e}$ and $\mathrm{f}$ ). As a note, DT40 triple knockout cells remained responsive to nutrient starvation as their wild-type counterparts (Figure 1f), suggesting that at least two independent signaling pathways to autophagy - which are activated by distinct triggers - coexist in these cells. As described earlier, ${ }^{29}$ xestospongin B caused the dissociation of the Beclin 1/Bcl-2 complex that normally inhibits autophagy. This effect could be detected in coimmunoprecipitation experiments when xestospongin B was added to control DT40 cells, yet was undetectable in $\mathrm{IP}_{3} \mathrm{R}$-deficient DT40 cells (Figure $1 \mathrm{~g}$ and $\mathrm{h}$ ).

The redistribution of GFP-LC3 to dots or the accumulation of LC3-II may be a sign of an enhanced formation of autophagosomes or a reduced removal of autophagosomes. ${ }^{33,34}$ To discriminate between these two possibilities, we blocked the fusion between autophagosomes and lysosomes (with bafilomycin A1) and/or inhibited lysosomal proteases (with pepstatin A). As an internal control of its efficacy, we ensured that bafilomycin A1 inhibited the colocalization of GFP-LC3 with the lysosomal marker Lamp $2 \mathrm{~A}$, which is an indicator of the autophagosome-lysosome fusion (Figure $2 \mathrm{a}$ and $\mathrm{b}$ ). In these conditions, the addition of xestospongin B continued to induce an increase in GFP-LC3 puncta (Figure 2a and $\mathrm{c}$ ) and in the generation of LC3-II (Figure $2 \mathrm{~d}$ and $\mathrm{e}$ ), which strengthens the notion that xestospongin $B$ stimulates the initiation, rather than the late stages, of the autophagic flux.

Xestospongin $B$ neither affected the basal levels nor the histamine-induced increase of $\mathrm{IP}_{3}$ (Figure 3a). In conditions in which the IMP inhibitor L-690330 reduced IP 3 levels, nontoxic doses of myo-inositol (which lead to an increase in $\mathrm{IP}_{3}$ concentrations) inhibited L-690330-induced autophagy, but failed to suppress autophagy induced by xestospongin $B$ (Figure 3b). From these results, we conclude that xestospongin $\mathrm{B}$ induces autophagosome formation through a Bcl-2inhibitable effect on $I P_{3} R$ that does not involve major perturbations of inositol metabolism.

A molecular complex involving the $I P_{3} R$ and Beclin 1
regulates autophagy in response to xestospongin $B$ or
starvation. Driven by the observation that Bcl-2
overexpression can inhibit xestospongin $B$-induced
autophagy, we monitored the molecular interaction between
the $I P_{3} R$ and Beclin 1 , which so far has been indicated as the
main target for $B c l-2-$ mediated autophagy inhibition. ${ }^{14,15}$ In
unstimulated cells, $I P_{3} R$ could be immunoprecipitated with


a

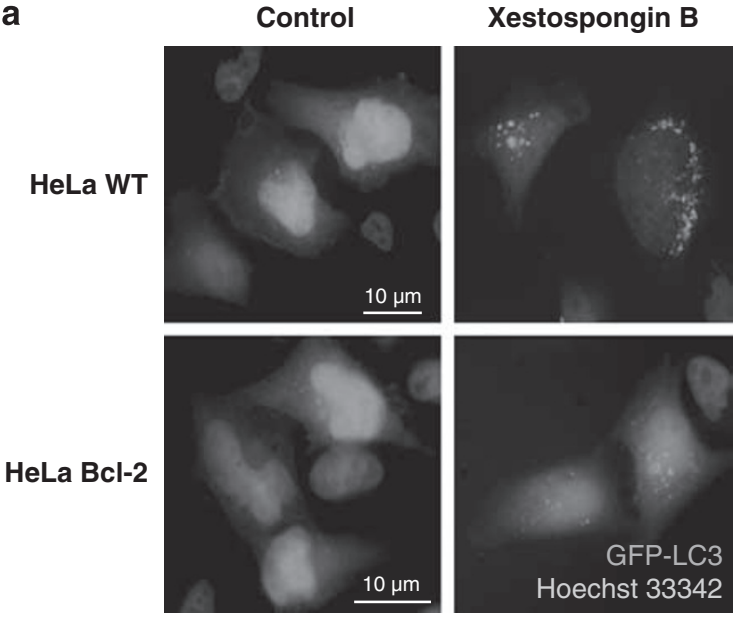

c

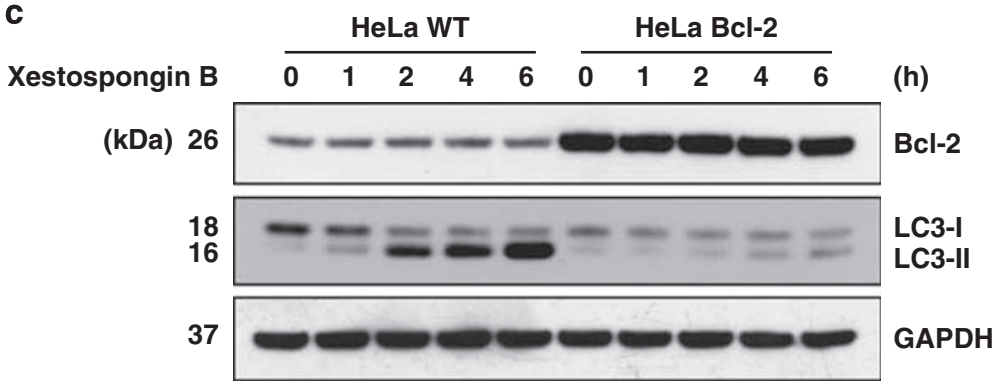

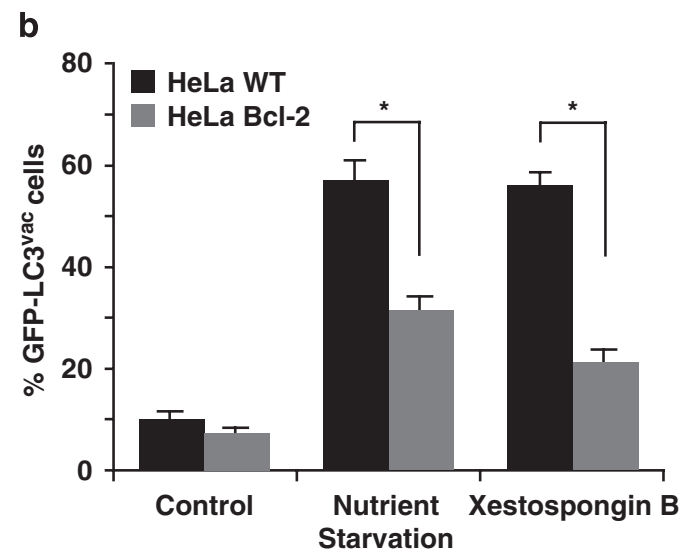

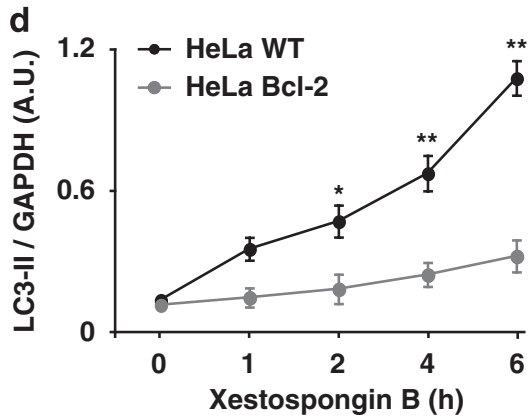

e

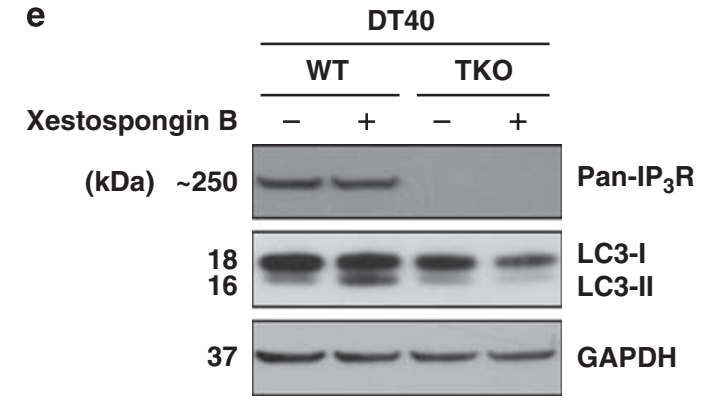

g

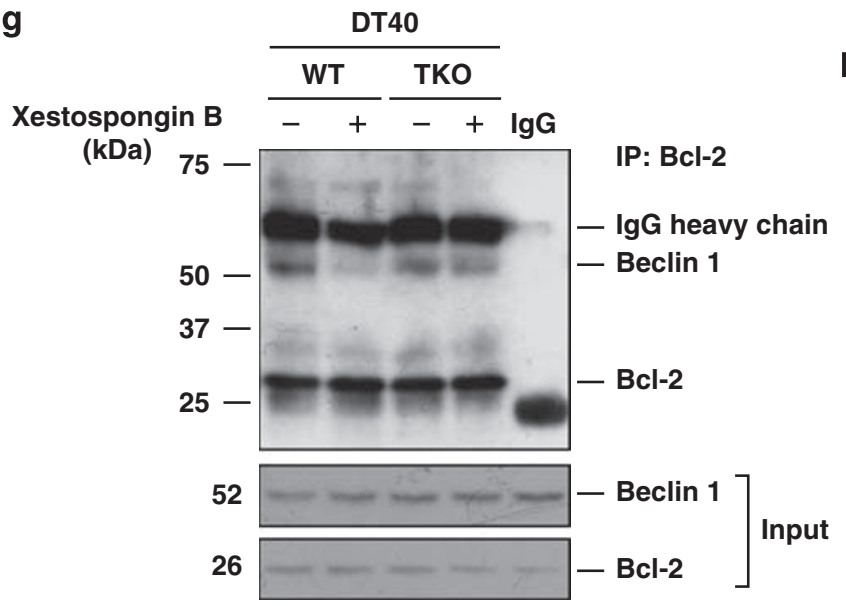

f

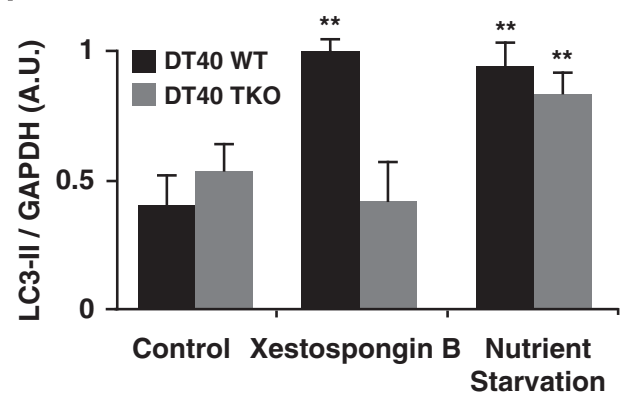

h

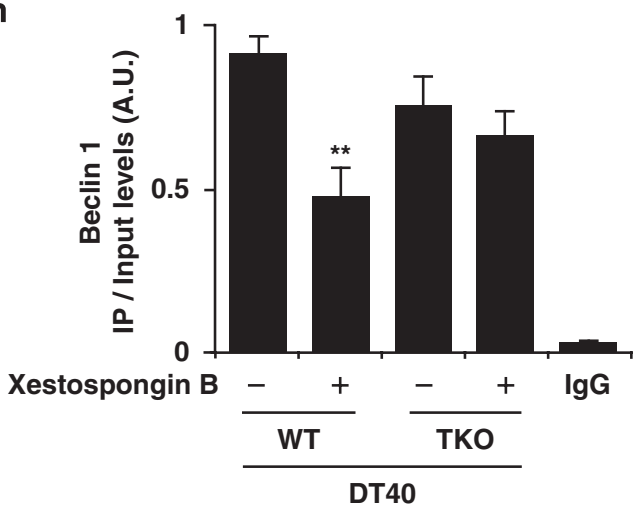


Beclin 1 and vice versa. Shortly after addition of xestospongin B (usually within $3 \mathrm{~h}$ ), this interaction was reduced (Figure $4 a$ and $b$ ). As described earlier by our group, xestospongin $B$ disrupted the interaction between Beclin 1 and $\mathrm{Bcl}-2,{ }^{29}$ whereas it did not affect the co-immunoprecipitation between the $\mathrm{IP}_{3} \mathrm{R}$ and $\mathrm{Bcl}-2$ (Figure 4c). This suggests that xestospongin $B$ disrupts the interaction between Beclin 1 and the $\mathrm{IP}_{3} \mathrm{R} / \mathrm{Bcl}-2$ complex. Similar results were found when xestospongin $B$ treatment was replaced by the most physiological inducer of autophagy, nutrient starvation (Figure 4d), and could also be detected in different cell lines, including human colon cancer HCT116 cells and Rat-1 fibroblasts (not shown). In cells that overexpress Bcl-2, the capacity of xestospongin $B$ to disrupt the $\mathrm{IP}_{3} \mathrm{R} /$ Beclin 1 complex was reduced and delayed (Figure 4e). Importantly, when Bcl-2 was depleted by specific siRNAs (Figure 4f), the $\mathrm{IP}_{3} \mathrm{R} /$ Beclin 1 complex was disrupted in resting conditions (Figure $4 \mathrm{~g}$ ), further corroborating the notion that the interaction between $I P_{3} R$ and Beclin 1 is mediated by Bcl-2. Although mTOR phosphorylation and mTOR-mediated phosphorylation of $\mathrm{p} 70^{\mathrm{S} 6 \mathrm{~K}}$ were inhibited by rapamycin, xestospongin $\mathrm{B}$ did not affect mTOR phosphorylation or $\mathrm{p} 70^{\mathrm{S6K}}$ phosphorylation (Figure 5a). Moreover, mTOR inhibition with rapamycin, which induces autophagy, failed to disrupt the $\mathrm{IP}_{3} \mathrm{R} /$ Beclin 1 complex (Figure 5b). Altogether, these results strongly suggest that the inhibition of mTOR and that of the $I_{3} R$ induce autophagy through mechanisms that can be fully separated.

As several $\mathrm{IP}_{3} \mathrm{R}$-interacting proteins, including $\mathrm{Bcl}-2$, have major effects on $\mathrm{Ca}^{2+}$ signaling, ${ }^{27}$ we tested whether Beclin 1 might also affect $\mathrm{Ca}^{2+}$ homeostasis, which reportedly has an important impact on autophagy. ${ }^{18-22}$ However, we did not detect any tangible effect of Beclin 1 depletion on $I_{3} R$ agonist-induced $\mathrm{Ca}^{2+}$ fluxes (Figure $6 \mathrm{a}$ and $\mathrm{b}$ ), steady state levels of $\mathrm{Ca}^{2+}$ in the ER lumen, thapsigargin-induced $\mathrm{Ca}^{2+}$ depletion from the ER (Figure $6 \mathrm{c}$ ), or increases in cytosolic $\left[\mathrm{Ca}^{2+}\right]$ upon inhibition of the sarco-ER $\mathrm{Ca}^{2+}$ ATPase (SERCA) with 2,5-di(ter-butyl)-1,4 benzohydroquinone (tBHQ; Figure $6 \mathrm{~d}$ and e). This was assessed by using stateof-the-art aequorin-based $\mathrm{Ca}^{2+}$ sensors (Figure $6 \mathrm{a}$ and $\mathrm{b}$ ), ERD1 cameleon $\mathrm{Ca}^{2+}$ sensor (Figure $6 \mathrm{c}$ ) or a chemical $\mathrm{Ca}^{2+}$ probe (Figure $6 \mathrm{~d}$ and e). Collectively, these data indicate that the $\mathrm{IP}_{3} \mathrm{R}$ can affect the autophagy-inducing function of Beclin 1 , yet suggest that Beclin 1 itself does not play a major role in regulating $\mathrm{Ca}^{2+}$ fluxes governed by the $I P_{3} R$.

The $I_{3} R$ ligand-binding domain (IP $\left.P_{3} R-L B D\right)$ inhibits autophagy through an effect on the Beclin 1/Bcl-2 complex. $A$ target for xestospongin $B$ is the $I P_{3} R$-LBD (aa 224-604), which is engaged in several protein-protein interactions; ${ }^{35,36}$ and has a major effect on the regulation of ER-mitochondrial microdomains that affect $\mathrm{Ca}^{2+}$ signaling and the physical contact between ER and mitochondria. ${ }^{24}$ The transfection-enforced expression of the $I P_{3} R$-LBD coupled to red fluorescent protein (RFP) strongly inhibited autophagy induced by xestospongin $B$ or nutrient starvation (Figure 7a and $b$ ). This held so for either ER-targeted, outer mitochondrial membrane (OMM)-targeted and cytosolic (Cyto) variants of the $I_{3} R-L B D$ coupled to RFP, all of which affect the ER-mitochondrial cross-talk. ${ }^{24}$ As negative controls, equally targeted versions of RFP (namely Cyto-ERand OMM-RFP) failed to inhibit autophagy in this system, as assessed by measuring GFP-LC3 puncta (Figure 7a and b) or the accumulation of LC3-II (Figure 7e). Moreover, an inactive $I_{3} R$-LBD mutant $\left(I_{3} R\right.$-LBD-9aaER-RFP) in which the insertion of a nonapeptide linker abolishes the interaction with endogenous $I P_{3} R,{ }^{37}$ failed to affect xestospongin $B-$ induced autophagy (Figure $7 \mathrm{~b}$ ). All the functional variants of the IP ${ }_{3}$ R-LBD-RFP (Cyto-, OMM- and ER-targeted) but not $I_{3} R$-LBD-9aaER-RFP, interacted with Beclin 1 (not shown), and this interaction was reduced in the ER by depletion of $\mathrm{Bcl}-2$ (Figure $7 \mathrm{c}$ and $\mathrm{d}$ ). Altogether, these results indicate that $I P_{3} R$-LBD is the moiety of the $I_{3} R$ that mediates its interaction with Beclin 1 (through Bcl-2), and accounts for $\mathrm{IP}_{3} \mathrm{R}$-mediated inhibition of autophagy.

\section{Conclusions}

The results from this and several earlier studies, ${ }^{17,18,29,30}$ indicate that $I P_{3} R$ agonists (such as $I P_{3}$ itself) and $I P_{3} R$ antagonists (such as xestospongins) act as inhibitors and inducers of autophagy, respectively, through an effect on the $I P_{3} R$. Thus, xestospongin $B$, which reportedly competes with $I P_{3}$ for $I P_{3} R$ binding, ${ }^{38,39}$ induces autophagy through the $I P_{3} R$ (in the sense that this effect is lost in $\mathrm{IP}_{3} \mathrm{R}$ knockout cells) rather than through an off-target effect. Although acute depletion of the $I P_{3} R$ by $R N A$ interference is sufficient to induce autophagy in HeLa cells, ${ }^{29}$ permanent $I_{3} R$ knockout by homologous recombination does not induce autophagy, at least in DT40 cells, presumably because these cells have adapted to the absence of the $\mathrm{IP}_{3} \mathrm{R}$ in a long-term selection process and express a truncated version of $\mathrm{IP}_{3} \mathrm{R} .{ }^{40}$ Conversely, plasmid-driven overexpression of the $I_{3} R$-LBD inhibits autophagic vacuolization induced by both xestospongin and nutrient starvation, further confirming the major impact of the $\mathrm{IP}_{3} \mathrm{R}$ on the regulation of autophagy.

Although accumulating evidence point to the modulation of autophagy by the $I P_{3} R$, the underlying mechanisms are still

Figure 1 Induction of autophagy by xestospongin B is dependent on the $\mathrm{P}_{3} \mathrm{R}$ and $\mathrm{Bcl}-2$. Bcl-2 inhibits xestospongin B-induced autophagy (a-d). Wild-type (WT) or Bcl-2 overexpressing HeLa cells transfected with GFP-LC3 were treated with xestospongin B $(2 \mu \mathrm{M})$ for $4 \mathrm{~h}$. Autophagy was monitored by assessing the intracellular redistribution of GFP-LC3 (a), and the percentage of vacuolizated cells was quantified (b). LC3 lipidation was compared between WT and Bcl-2 overexpressing HeLa cells by immunoblotting (c), and quantified (d) at the times indicated. The $\mathrm{IP}_{3} \mathrm{R}$ was necessary for xestospongin B-(4h), but not starvation-mediated (2 $\left.\mathrm{h}\right)$ LC3 lipidation, as observed in WT DT40 chicken B lymphocytes versus a triple knockout (TKO) DT40 cell line deficient for all $I P_{3} R$ isoforms (e and f). Bcl-2 and Beclin 1 interaction was monitored after $6 \mathrm{~h}$ of xestospongin B treatment in WT versus TKO DT40 cells $(\mathbf{g})$, and the coimmunoprecipitated levels of Beclin 1 were normalized to input levels (h). Results are representative of at least three independent experiments. ${ }^{\star} P<0.05$ and ${ }^{\star \star} P<0.01$ as indicated for WT compared with genetically modified cells. The colour reproduction of this figure is available on the $\mathrm{html}$ full version of the manuscript 
a
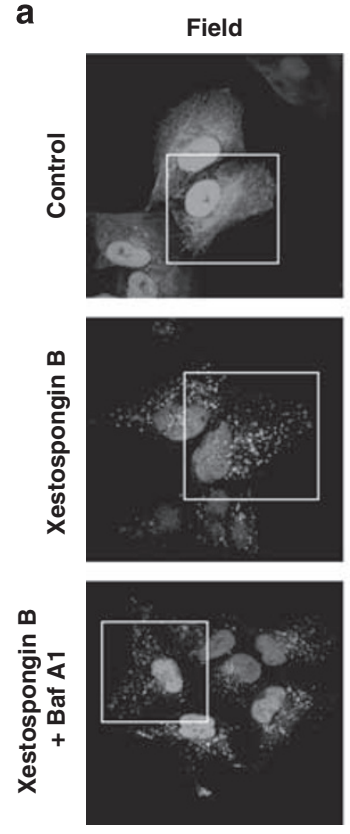

GFP-LC3
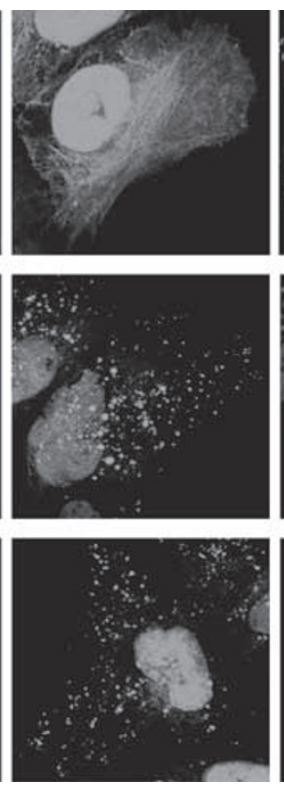

Lamp 2a
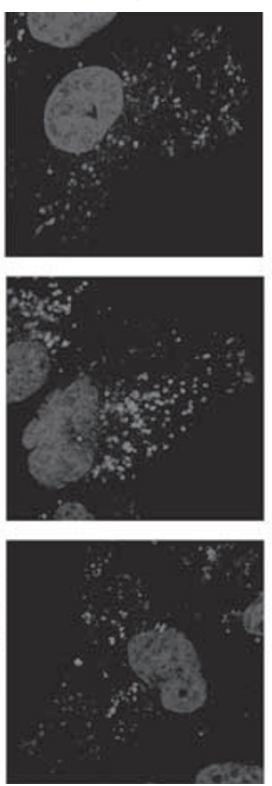

Overlay
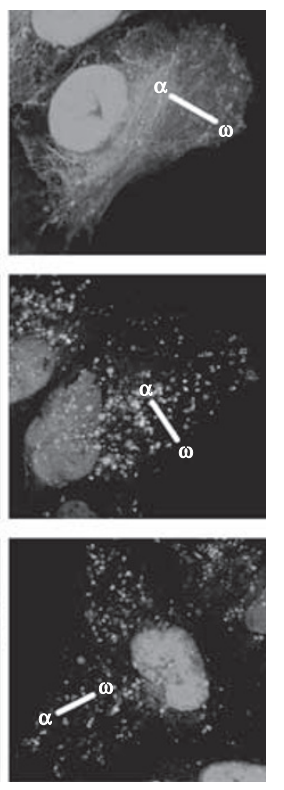
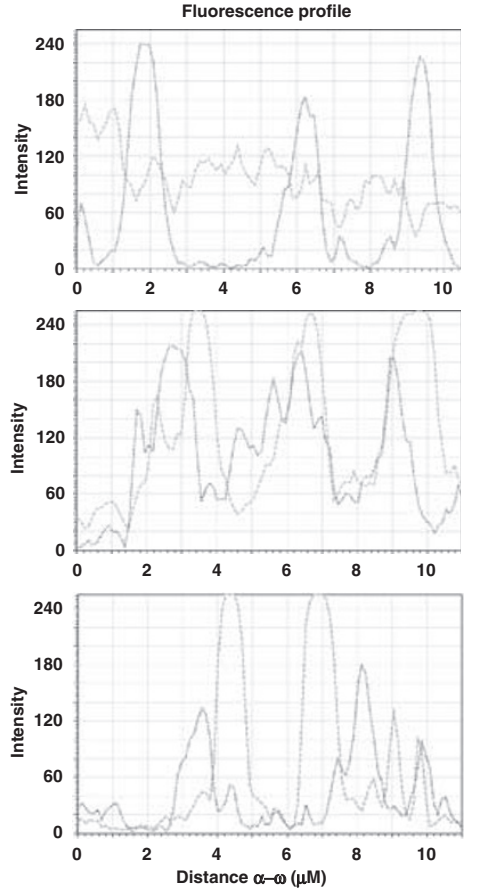

b

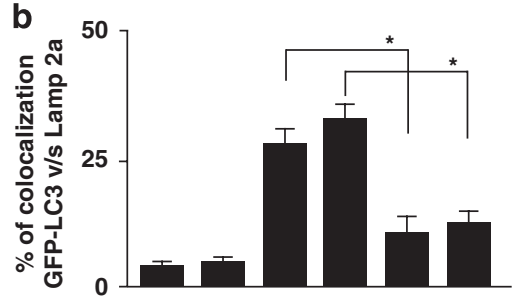

c

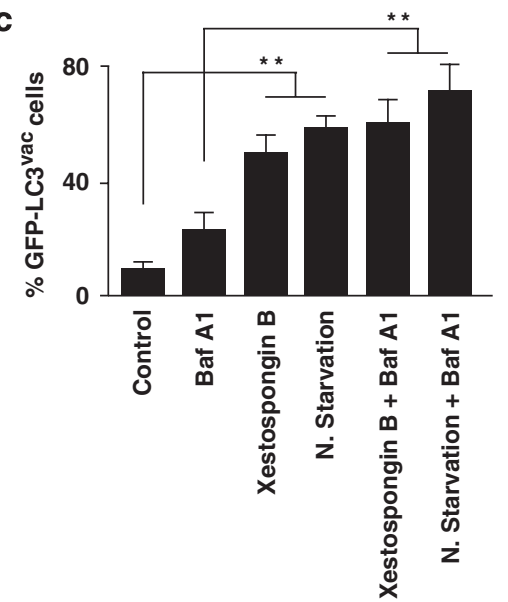

d

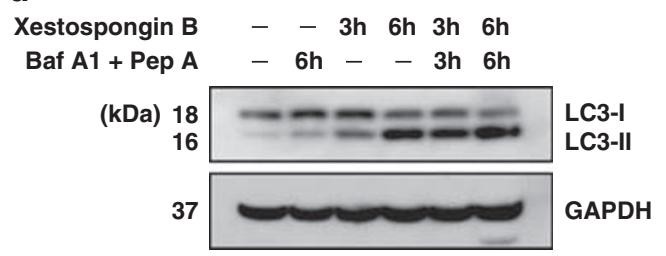

e

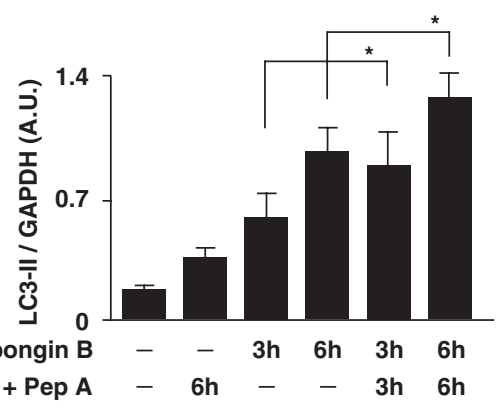

Figure 2 On-rate autophagic flux induced by xestospongin B. HeLa cells transiently expressing GFP-LC3 were preincubated ( 30 min) with bafilomycin A1 and then subjected to xestospongin $B$ treatment $(4 \mathrm{~h})$ or to nutrient starvation $(2 \mathrm{~h})$. Confocal images were acquired, the degree of colocalization between GFP-LC3 and the lysosomal marker Lamp 2a was quantified (a and $\mathbf{b}$ ), and the percentage of cells with GFP-LC3 puncta was determined (c). A mixture of bafilomycin A1 (1 nM) and pepstatin A1 $(10 \mu \mathrm{g} / \mathrm{ml})$ was employed to inhibit the lysosomal degradation of LC3-II (d). LC3-II relative to GAPDH levels were quantified (e). ${ }^{*} P<0.05 ;{ }^{\star *} P<0.01$ as indicated. The colour reproduction of this figure is available on the $\mathrm{html}$ full version of the manuscript

unclear. $\mathrm{IP}_{3} \mathrm{R}$ controls the agonist-induced release of $\mathrm{Ca}^{2+}$ from the ER lumen to the cytosol, ${ }^{35}$ and elevations of cytosolic $\mathrm{Ca}^{2+}$ have been involved in pharmacologically induced autophagy, as occurred in response to vitamin $D$ analogs. ${ }^{22}$ Hence, the finding that $\mathrm{IP}_{3} \mathrm{R}$ inhibition with xestospongins induces autophagy (although it should reduce ${ }^{39}$ cytosolic $\mathrm{Ca}^{2+}$ ) suggests that the effects of the $\mathrm{IP}_{3} \mathrm{R}$ and/or $\mathrm{IP}_{3} \mathrm{R}$ ligands on autophagy cannot be explained only by a modulation of $\mathrm{Ca}^{2+}$ levels. Here, we show that the $\mathrm{IP}_{3} \mathrm{R}$ coimmunoprecipitates with Beclin 1, suggesting another 
a

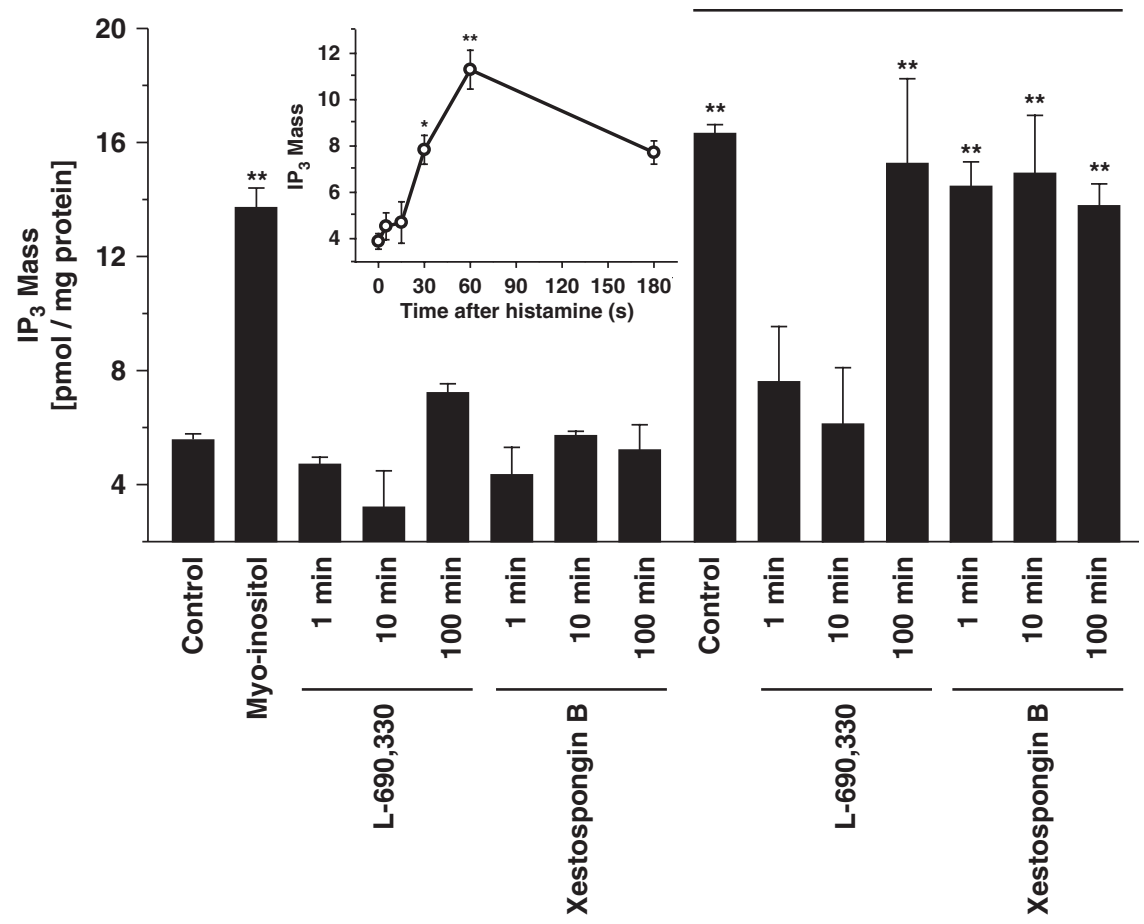

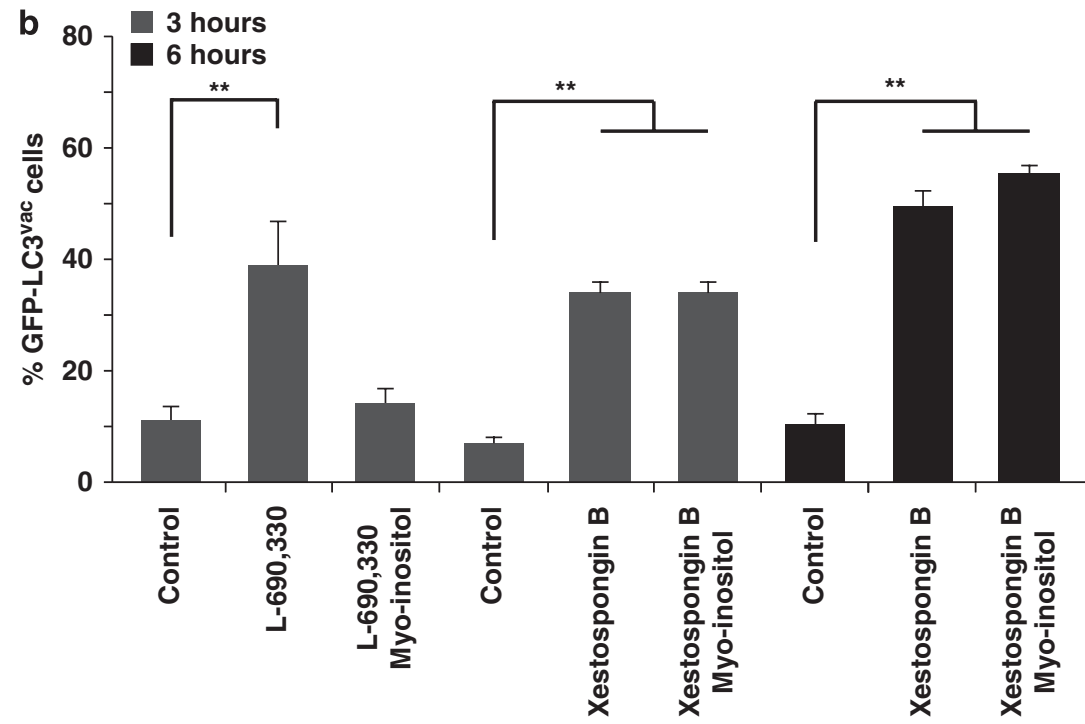

Figure 3 Autophagy induced by xestospongin $\mathrm{B}$ is $\mathrm{IP}_{3}$-independent. Intracellular levels of the transient messenger $\mathrm{IP}_{3}$ were measured with a radioreceptor assay under basal or histamine-induced peak conditions (a). The inset graphic depicts a typical time-response to identify the time of $\mathrm{IP}_{3}$ peak concentrations, as induced by histamine $(100 \mu \mathrm{M})$ stimulation. Treatment with myo-inositol $(10 \mu \mathrm{M}, 10 \mathrm{~min}), \mathrm{L}-690330(100 \mu \mathrm{M})$ and xestospongin $\mathrm{B}(2 \mu \mathrm{M})$ were compared under basal as well as peak conditions evoked by histamine (a). HeLa cells transiently expressing GFP-LC3 were treated with xestospongin B in the presence or absence of myo-inositol. The percentage of vacuolizated cells was determined at the indicated times (b). Data are presented as mean \pm S.E.M. of three independent triplicates. ${ }^{*} P<0.05$ and ${ }^{\star *} P<0.01$ versus unstimulated control (a) or as indicated (b)

mechanism through which the $\mathrm{IP}_{3} \mathrm{R}$ might act as an endogenous inhibitor of autophagy. Indeed, we found that $I P_{3} R$ binding by its antagonist xestospongin $B$, as well as physiological induction of autophagy by nutrient starvation, disrupted the interaction between the $I_{3} R$ and Beclin 1. As this interaction was abolished by the knockdown of $\mathrm{Bcl}-2$, it is likely that the $\mathrm{IP}_{3} \mathrm{R}$ and Beclin 1 interact through an indirect link established by Bcl-2.
In the triangular game among the $\mathrm{IP}_{3} \mathrm{R}$, Beclin 1 and $\mathrm{Bcl}-2$, the $I P_{3} R$-LBD (which is the site of interaction with $I P_{3}$ and xestospongins) appears as the most important domain for the regulation of autophagy. Thus, the $I P_{3} R-L B D$ (which itself has no function as a $\mathrm{Ca}^{2+}$ channel) ${ }^{41}$ can inhibit autophagy irrespective of its precise subcellular localization or topology, once more arguing against the idea that modified $\mathrm{Ca}^{2+}$ fluxes account for the effects of $\mathrm{IP}_{3} \mathrm{R}$ on autophagy. We were unable 
a
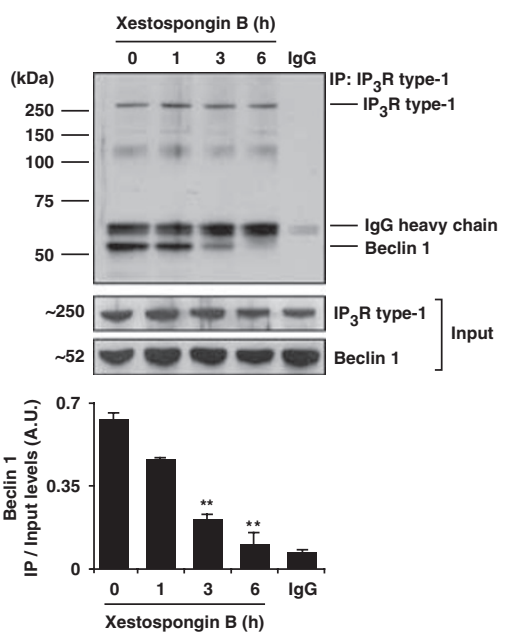

b
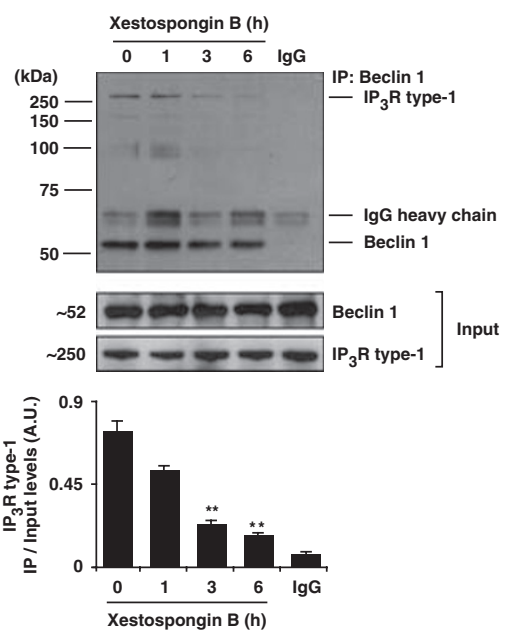

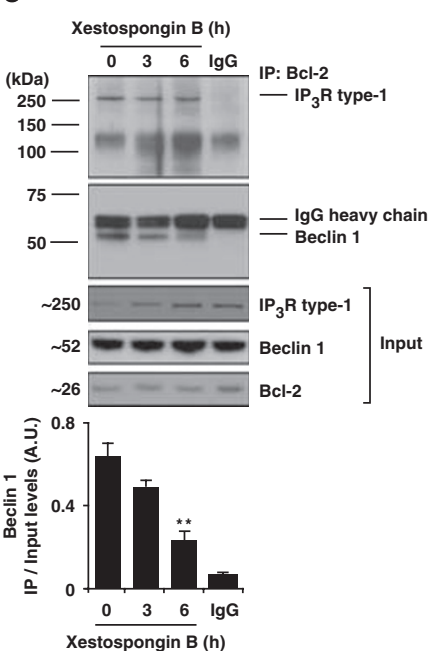

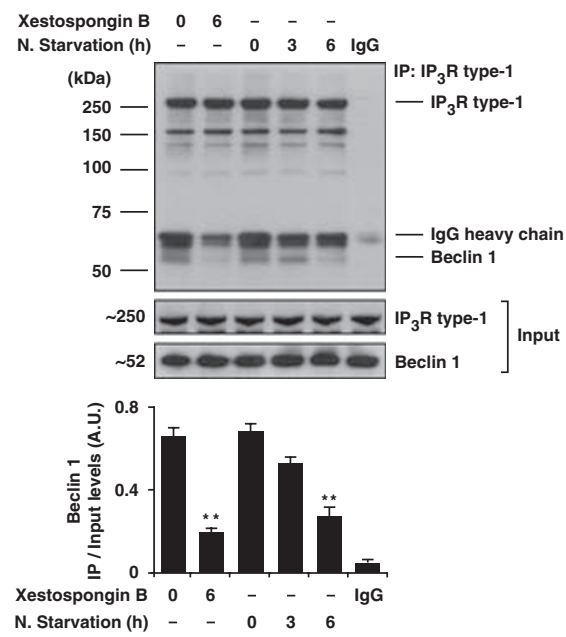

e

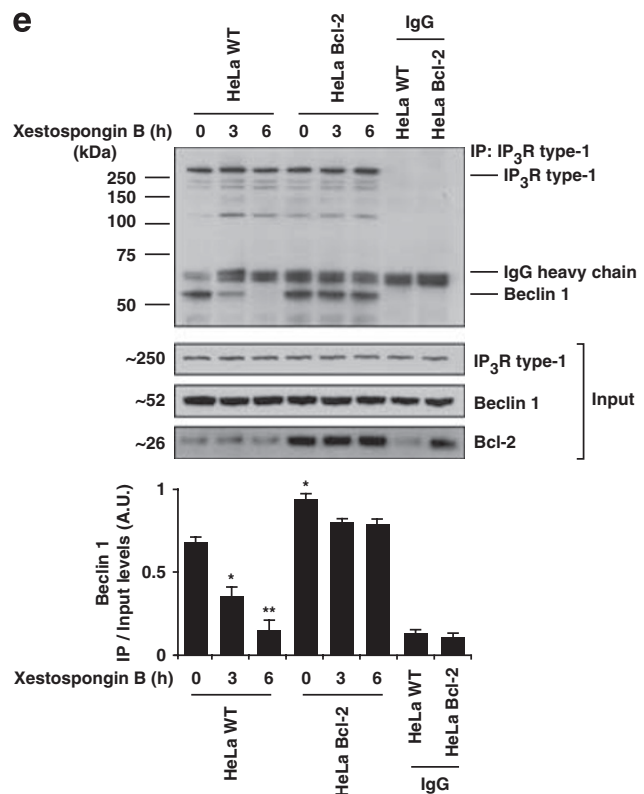

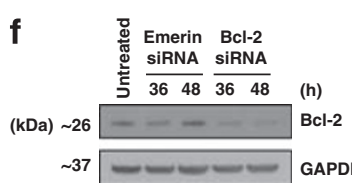

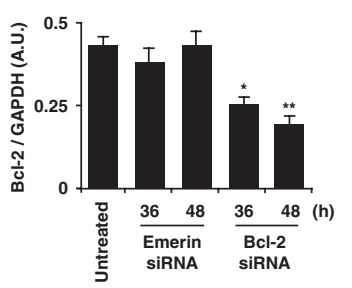

g

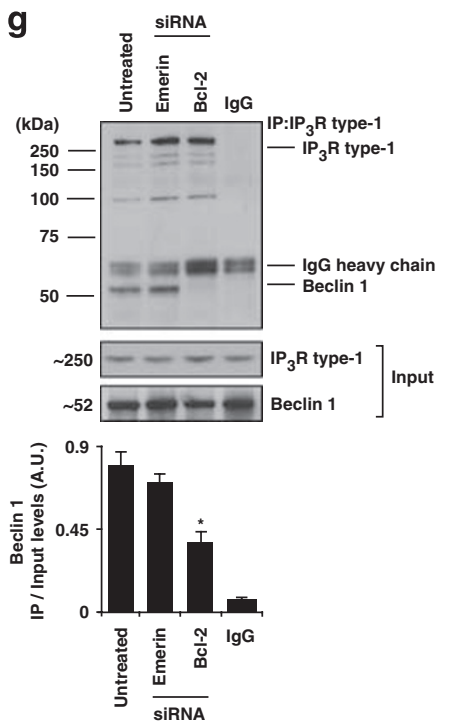

Figure 4 A Bcl-2-dependent molecular complex comprising the $\mathrm{IP}_{3} \mathrm{R}$ and Beclin 1 regulates autophagy. Immunoprecipitation assays were carried out as indicated in Materials and Methods using wild-type (WT) (a-d) and Bcl-2 overexpressing HeLa cells (e), as well as HeLa cells in which Bcl-2 was depleted by specific siRNAs $(\mathbf{g})$. Xestospongin $B$ induces the dissociation of Beclin 1 from the $I P_{3} R(\mathbf{a})$ and vice versa $(\mathbf{b})$, as well as the separation of Beclin-1 from $B c l-2$, without affecting the interaction between the $\mathrm{IP}_{3} \mathrm{R}$ and $\mathrm{Bcl}-2$ (c). Under nutrient starvation conditions, the interaction between Beclin 1 and the $I \mathrm{P}_{3} \mathrm{R}$ was also lost (d). In HeLa cells, stably overexpressing $\mathrm{Bcl}-2$, the xestospongin B-mediated dissociation of Beclin 1 from the $I_{3} R$ was reduced, compared with WT HeLa cells (e). Conversely, in HeLa cells depleted of Bcl-2 (f), the interaction between Beclin 1 and the $I P_{3} R$ was already lost in unstimulated conditions $(\mathbf{g})$. In all experiments, coimmunoprecipitated protein levels were quantified relative to input protein levels. Data are presented as mean \pm S.E.M. of three independent triplicate assessments. ${ }^{\star} P<0.05$ and ${ }^{* *} P<0.01$ versus untreated controls 


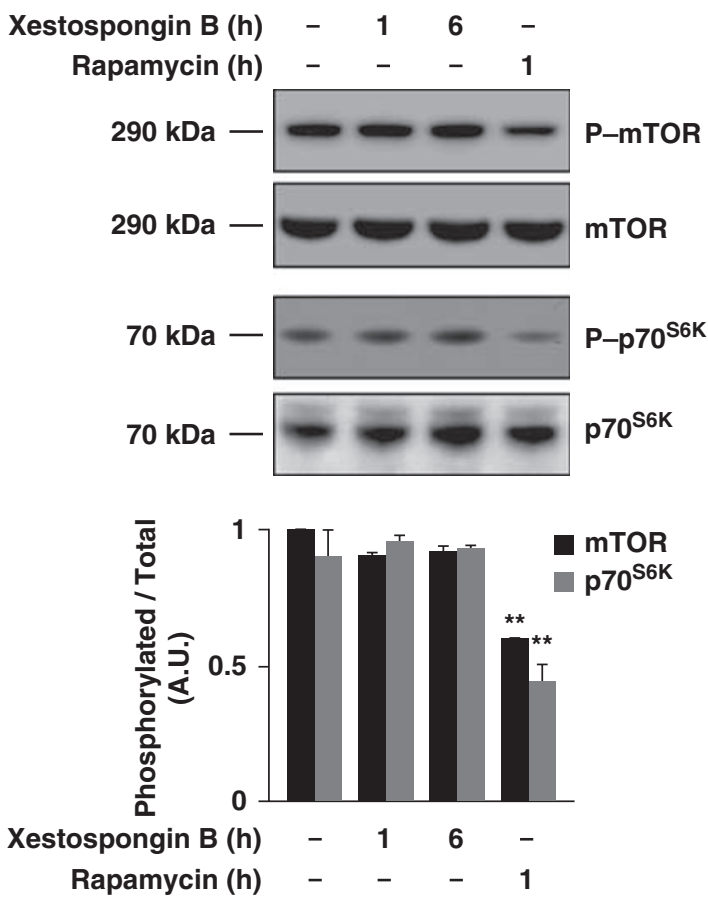

b

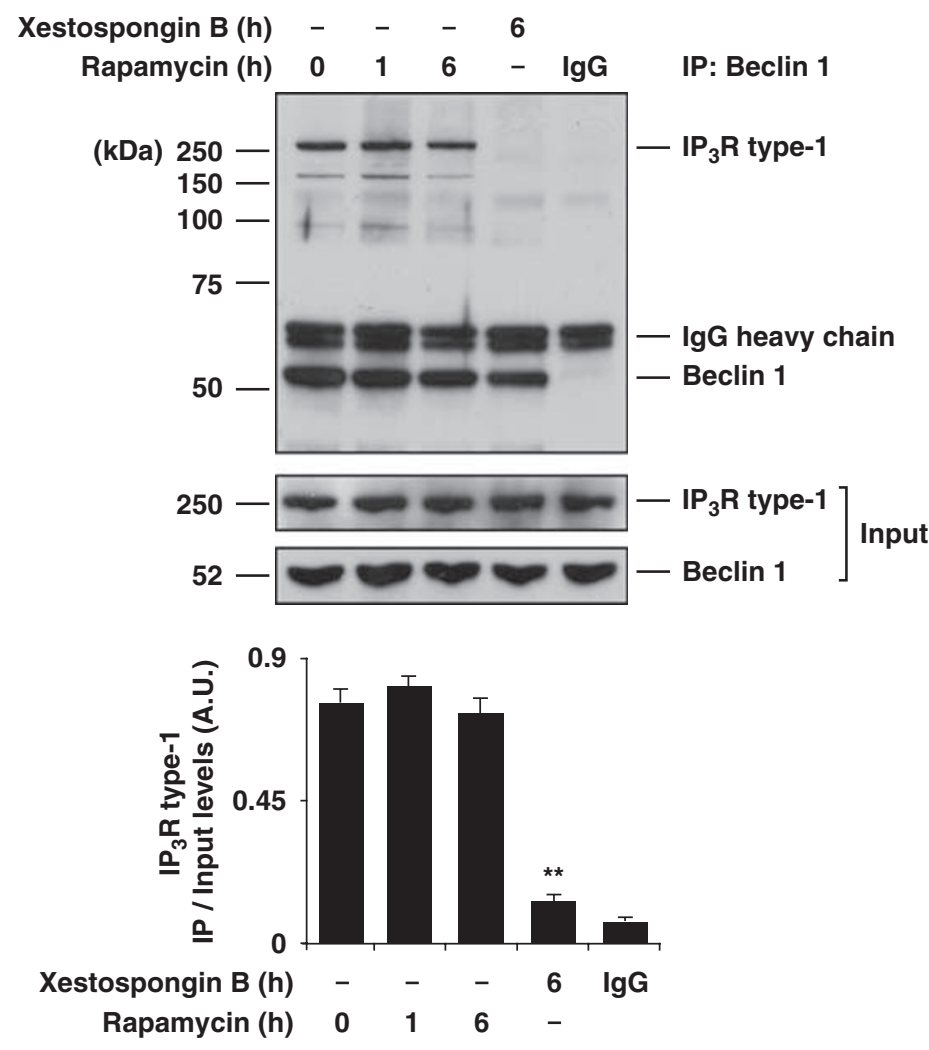

Figure 5 Xestospongin B effects are mTOR-independent. HeLa cells were treated with xestospongin $\mathrm{B}(2 \mu \mathrm{M})$ or rapamycin $(1 \mu \mathrm{M})$ for the indicated periods and the levels of $\mathrm{mTOR}$ and $\mathrm{p} 70^{\mathrm{S6 \textrm {K }}}$ phosphorylation were assessed by immunoblotting (a). The Beclin $1 / \mathrm{IP} \mathrm{P}_{3} \mathrm{R}$ interaction was not modified by rapamycin treatment, in conditions in which xestospongin $B$ caused its dissociation (b). Results are presented as mean \pm S.E.M. of three independent triplicate assessments. ${ }^{* \star} P<0.01$ versus untreated controls

to detect any effects of Beclin 1 knockdown on $\mathrm{Ca}^{2+}$ fluxes at the ER membrane, which suggests that Beclin 1 affects autophagy regulation mainly as an allosteric regulator of Vps34 (and perhaps other yet-to-be-discovered enzymatic activities and molecular motors), rather than through gross effects on $\mathrm{Ca}^{2+}$ handling.

In synthesis, the results contained in this study identify the $I_{3} R$ as a new, unsuspected regulator of the Beclin 1 complex that bridges signals converging on the $E R$ and initial phagophore formation. Although the molecular details of this cross-talk require further exploration, our data point to the presence of an intriguing regulatory network in which the conformation of the $\mathrm{IP}_{3} \mathrm{R}$, as influenced by agonists and/or antagonists acting on its $\mathrm{LBD}$, regulates the initiation of autophagy through an effect on Beclin 1.

\section{Materials and Methods}

Cells and treatments. Wild-type, Bcl-2 overexpressing and GFP-LC3 overexpressing derivatives of the human cervix adenocarcinoma HeLa cell line, as well as the rat fibroblast cell line Rat-1, were grown in Glutamax-containing Dulbecco's modified Eagle's medium supplemented with $10 \%$ heat-inactivated fetal bovine serum (FBS) and $10 \mathrm{mM}$ HEPES buffer. Wild-type and $\mathrm{IP}_{3} \mathrm{R}$-triple deficient chicken lymphoma DT40 cells were maintained in Glutamax-containing RPMI 1640 medium supplemented with 10\% FBS, $1 \%$ chicken serum, $10 \mathrm{mM}$ HEPES buffer and $10 \mu \mathrm{M}$ 2-mercaptoethanol. All cell lines were cultured in the presence of $100 \mathrm{U} / \mathrm{ml}$ penicillin $\mathrm{G}$ and $100 \mu \mathrm{g} / \mathrm{ml}$ streptomycin, at $37^{\circ} \mathrm{C}(5 \%) \mathrm{CO}_{2}$. All media and supplements for cell culture were purchased from Gibco-Invitrogen (Carlsbad, USA). For serum and amino-acid starvation, cells were cultured in serum-free
Earle's Balanced Salt Solution medium (Sigma-Aldrich, St. Louis, MO, USA), a condition that we refer to as 'nutrient starvation'. All cell lines were seeded in 6-, 12- or 24-well plates and grown for $24 \mathrm{~h}$ before treatments. Unless otherwise indicated, chemicals were purchased from Sigma-Aldrich. Bafilomycin A1 (1 nM), histamine $(1-100 \mu \mathrm{M}), \mathrm{L}-690330(100 \mu \mathrm{M}$; Tocris, Bristol, UK), myo-inositol $(10 \mu \mathrm{M}$; Calbiochem, Darmstadt, Germany), pepstatin A $(10 \mu \mathrm{g} / \mathrm{ml})$ and xestospongin $\mathrm{B}(2 \mu \mathrm{M}$, extracted from the marine sponge Xestospongia exigua as described earlier ${ }^{38,42}$ ) were added for $0-8 \mathrm{~h}$, as indicated.

Dynamic in vivo $\left[\mathrm{Ca}^{2+}\right]$ measurements. Basal and 2,5-di(ter-butyl)-1,4 benzohydroquinone (tBHQ)- or histamine-induced cytosolic $\mathrm{Ca}^{2+}$ signals were measured using either Fura-2 or the cytosolic version of the recombinant $\mathrm{Ca}^{2+}$ sensor aequorin (cytAEQ). All measurements were carried out in Krebs-Ringer modified buffer (KRB): $135 \mathrm{mM} \mathrm{NaCl}, 5 \mathrm{mM} \mathrm{KCl}, 1 \mathrm{mM} \mathrm{MgSO}_{4}, 0.4 \mathrm{mM} \mathrm{K}_{2} \mathrm{HPO}_{4}$, $5.5 \mathrm{mM}$ glucose, $20 \mathrm{mM}$ HEPES ( $\mathrm{pH}=7.4$ ), supplemented with $1 \mathrm{mM} \mathrm{CaCl}$. HeLa cells were loaded with $3 \mu \mathrm{M}$ Fura-2/AM in KRB for $20 \mathrm{~min}$ at $37^{\circ} \mathrm{C}$ and $10 \mathrm{~min}$ at RT. Cells were then perfused with KRB followed by $100 \mu \mathrm{M} \mathrm{tBHQ}$, and dye calibration was performed using ionomycin ( $1 \mu \mathrm{M}$, the highest peak value) and ionomycin/ EDTA $(1 \mu \mathrm{M} / 1 \mathrm{mM}$, the lowest peak value). Changes in emission at $520 \mathrm{~nm}$ after sequential excitation at 340 and $380 \mathrm{~nm}$ were recorded and calibrated into $\left[\mathrm{Ca}^{2+}\right]_{c}$ from the ratio of emitted fluorescence, on the basis of an earlier described procedure that used a dissociation constant of $224 \mathrm{nM}$ for Fura- $2 .{ }^{43}$ HeLa cells transiently expressing cytAEQ were administrated with coelenterazine and transferred to a perfusion chamber. The light signal was collected in a purposebuilt luminometer and calibrated into $\left[\mathrm{Ca}^{2+}\right]_{c}$ values as described earlier. ${ }^{44}$ To quantify the $\mathrm{Ca}^{2+}$ content of the ER, the fluorescence resonance energy transfer (FRET)-based ER-targeted ERD1 probe $^{45}$ was imaged using a Zeiss LSM 510 Meta laser confocal system (Carl Zeiss AG, Oberkochen, Germany). The probe was excited by a $405 \mathrm{~nm}$ laser diode, emission spectra were acquired at $420-600 \mathrm{~nm}$ and the yellow fluorescent protein (YFP) and cyan fluorescent protein (CFP) signals were obtained by unmixing the spectrum on the basis of previously registered 

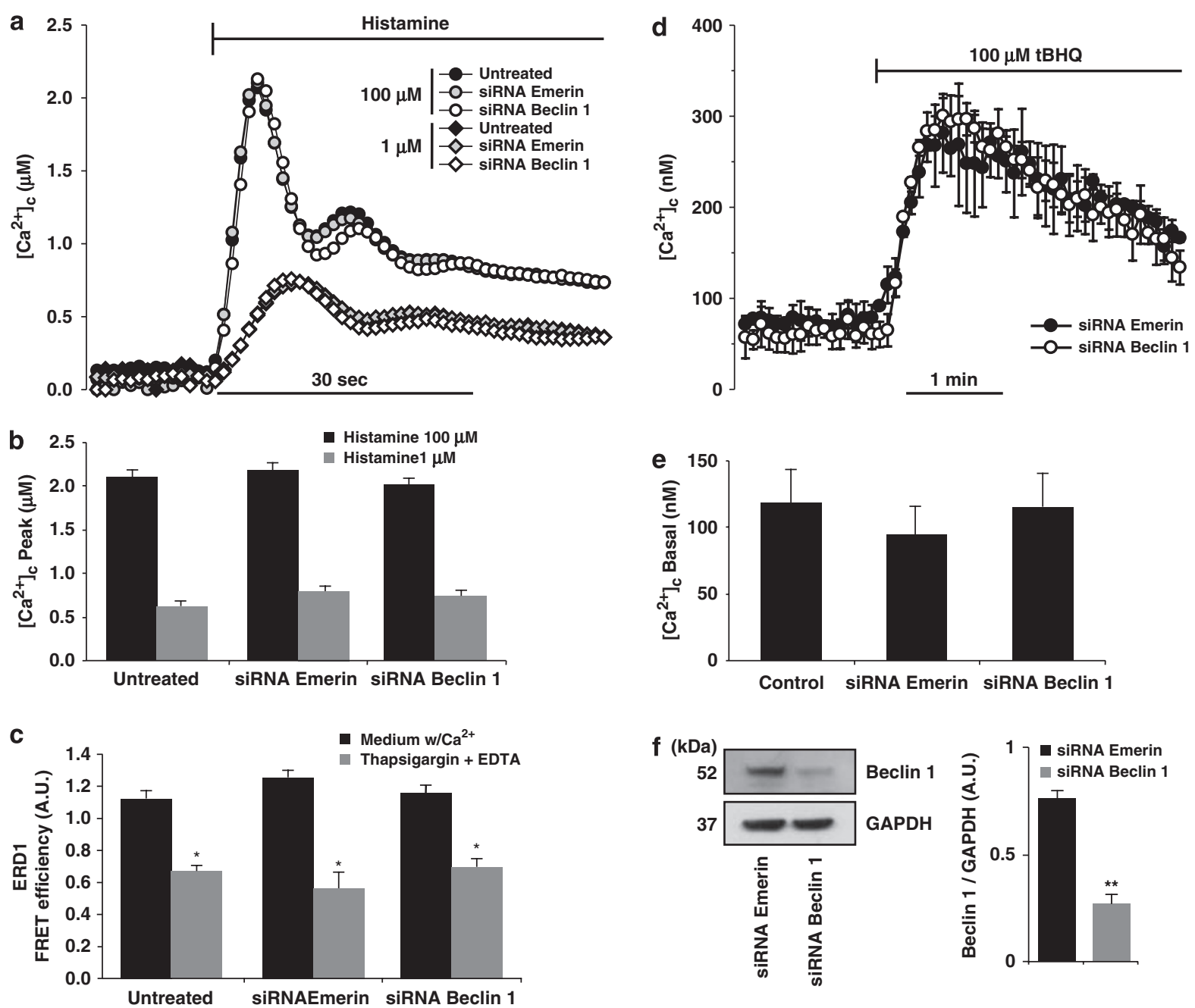

Figure 6 Beclin 1 depletion does not affect $\mathrm{Ca}^{2+}$ homeostasis. HeLa cells were transfected with specific siRNAs targeting Beclin 1 or the unrelated protein emerin. After $48 \mathrm{~h}$, cells were subjected to $\left[\mathrm{Ca}^{2+}\right.$ ] measurements (a-e) or immunoblotting to check Beclin 1 levels (f). Histamine-evoked (1 and $\left.100 \mu \mathrm{M}\right)$ cytosolic $\left[\mathrm{Ca}{ }^{2+}\right]$ increases were measured using cytAEQ. Representative traces (a) and mean \pm S.E.M. peak values are shown for each condition (b). Steady-state ER Ca ${ }^{2+}$ levels and thapsigargin-induced $\mathrm{ER} \mathrm{Ca}^{2+}$ depletion levels were measured with the FRET probe ERD1 and mean \pm S.E.M. values are shown (c). Cytosolic $\left[\mathrm{Ca}^{2+}\right.$ ] after ER depletion with $\mathrm{tBHQ}$ (d), as well as steady-state cytosolic $\mathrm{Ca}^{2+}$ levels (e) were quantified using Fura-2. Representative traces and mean values \pm S.E.M. are shown, respectively. ${ }^{*} P<0.05$ versus culture medium with $\mathrm{Ca}^{2+} .{ }^{*} \mathrm{P}<0.01$

spectra of separate CFP and YFP proteins, as well as the autofluorescence of nontransfected cells. FRET efficiency, which is a function of ER luminal $\left[\mathrm{Ca}^{2+}\right]$, was quantified using the acceptor bleaching method. ${ }^{45}$ Briefly, after five acquisitions, YFP was bleached (at both 488 and $514 \mathrm{~nm}$ excitation wavelengths, typically by about $80-90 \%$ ), followed by acquisition of further five image spectra. Reduction of the YFP signal leads to an increase in the CFP signal, which is normalized to the decrease of YFP intensity during bleaching. The normalized increase of CFP intensity is presented as FRET efficiency.

Immunoblots and immunoprecipitation. All cell lines $\left(4 \times 10^{6}\right.$ cells $)$ were washed with PBS and lysed as describe earlier. ${ }^{46}$ For immunoblotting, $50 \mu \mathrm{g}$ of protein were separated onto NuPAGE gels (Invitrogen) and transferred to Immobilion-PSQ PVDF membranes (Millipore Corporation, Billerica, MA, USA). Membranes were incubated for $1 \mathrm{~h}$ in PBS-Tween $20(0.05 \%)$ containing $5 \%$ BSA. Primary antibodies specific for Bcl-2, Beclin 1 (Santa Cruz Biotechnology, Santa Cruz, CA, USA), IP ${ }_{3} \mathrm{R}-\mathrm{I}$ (Calbiochem), IP ${ }_{3} \mathrm{R}$ types I-II-III (Santa Cruz), LC3B, mTOR, p70 ${ }^{\mathrm{SGK}}$, phospho-mTOR or phospho-p70 ${ }^{\mathrm{S} 6 \mathrm{~K}}$ (Cell Signaling, Danvers, MA, USA) were incubated overnight at $4{ }^{\circ} \mathrm{C}$ and revealed with the appropriate horseradish peroxidase-labeled secondary antibodies (SouthernBiotech, Birmingham, AL, USA) by means of the SuperSignal West Pico chemoluminiscent substrate (Pierce,
Rockford, IL, USA). An antibody recognizing GAPDH (Chemicon) was used to control equal loading of lanes. For immunoprecipitation, extracts from HeLa cells $\left(8 \times 10^{6}\right.$ cells) were lysed and $400 \mu \mathrm{g}$ of protein were precleared for $1 \mathrm{~h}$ with $15 \mu \mathrm{l}$ of Protein G Sepharose 4 Fast Flow (GE Healthcare, Piscataway, NJ, USA), and subsequently incubated for $3 \mathrm{~h}$ in the presence of anti-Beclin 1 antibody, anti-I $\mathrm{P}_{3} \mathrm{R}-\mathrm{I}$, anti-RFP (Abcam, Cambridge, UK) and anti-Bcl-2 or immunoglobulin control. Immunoprecipitation immunoblotting was carried out using TrueBlot-HRP (eBioscience, San Diego, CA, USA) secondary antibodies. Quantitative analysis of immunoblots was carried out by using the open source ImageJ software (freely available at http://rsbweb.nih.gov/ij/index.html). Results are presented as mean \pm S.E.M. Three independent experiments were carried out in triplicate, and statistical significance was evaluated by Student's $t$-test.

Immunofluorescence microscopy. For immunofluorescence staining, cells were fixed with paraformaldehyde ( $4 \% \mathrm{w} / \mathrm{v}, 20 \mathrm{~min}$ ), permeabilized with Triton $\mathrm{X}-100$ ( $0.3 \%$ in PBS, $30 \mathrm{~min}$ ), blocked with $3 \% \mathrm{BSA}$ and incubated overnight at $4{ }^{\circ} \mathrm{C}$ with a specific antibody against Lamp $2 a(200 \mathrm{ng} / \mathrm{ml}$; Santa Cruz). Nuclei were counterstained with $10 \mu \mathrm{g} / \mathrm{ml}$ Hoechst 33342 (Molecular Probes-Invitrogen, Carlsbad, CA, USA). Conventional fluorescence microscopy was performed with a Leica IRE2 microscope equipped with a DC300F camera (Leica Microsystems, 


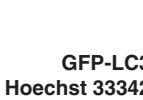
|

RFP Hoechst 33342

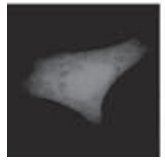

Xestospongin B

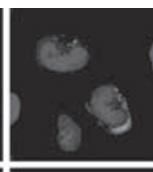

GFP-LC3 Hoechst 33342

$$
\text { (n) }
$$

$\mathrm{IP}_{3}$ R-LBD-RFP Hoechst 33342

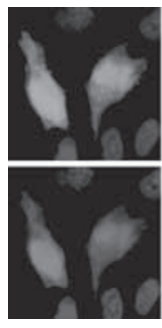

Cyto
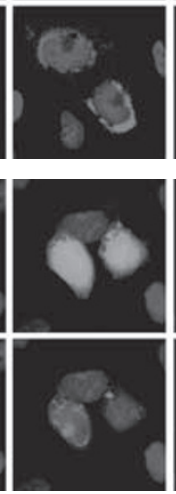

ER
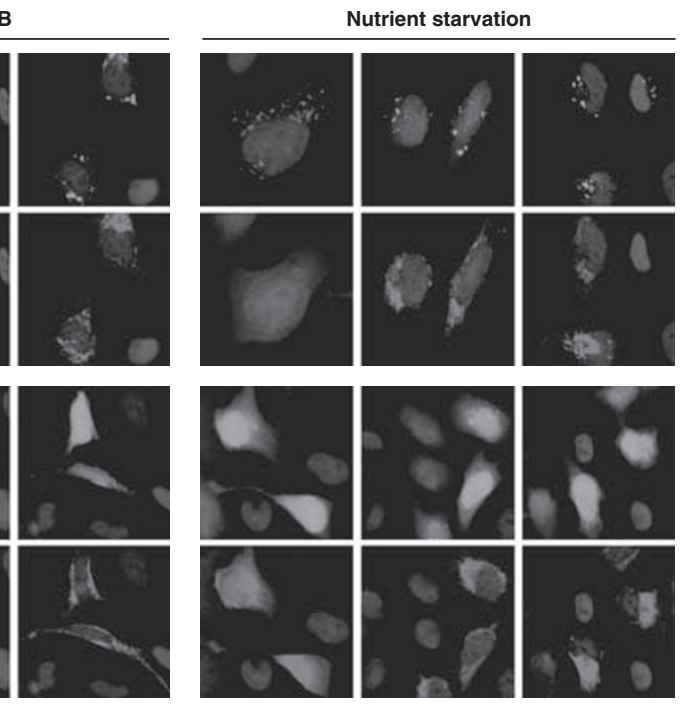

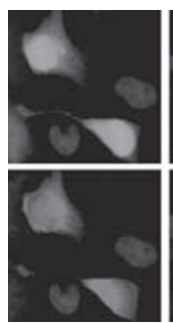

Cyto

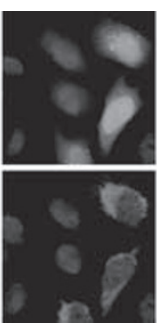

ER

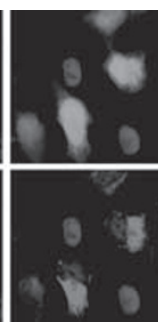

OMM

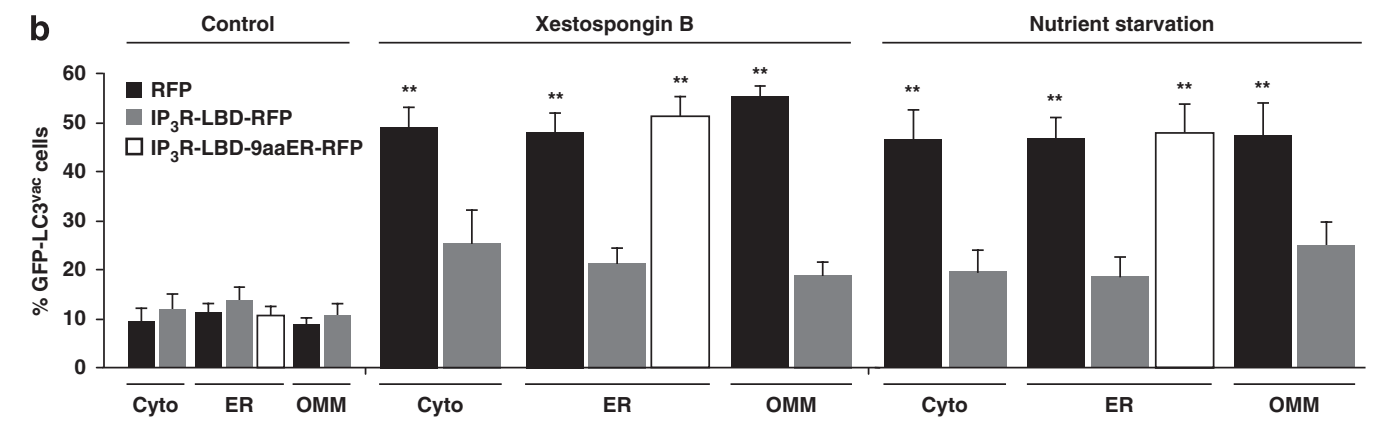

c

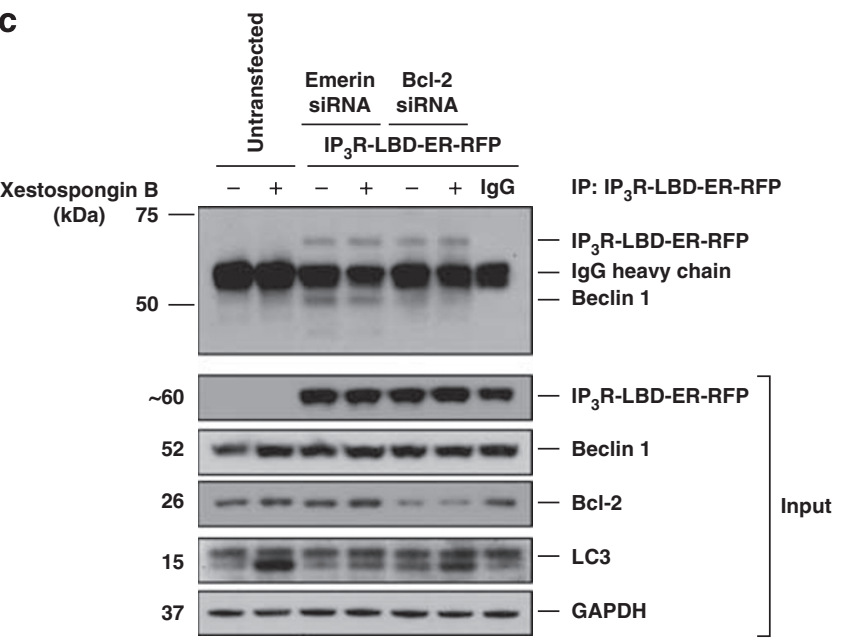

d

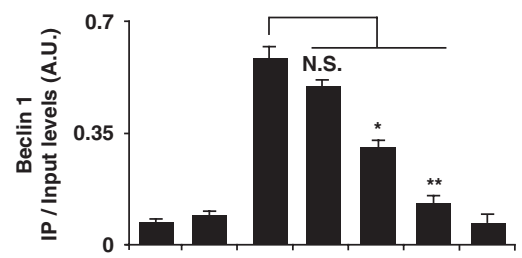

e

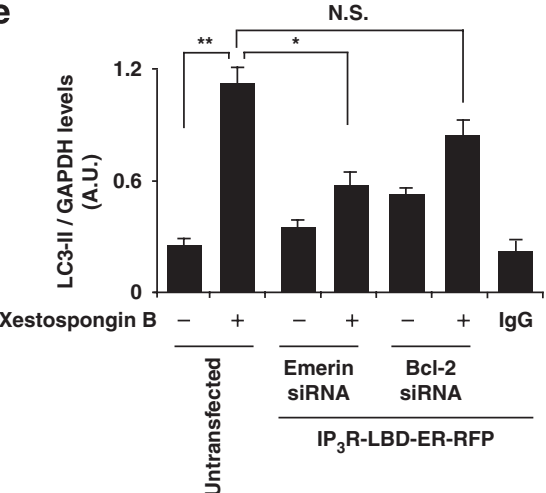

Figure 7 Overexpression of the $\mathrm{PP}_{3} \mathrm{R}$-LBD inhibits xestospongin B-induced autophagy through interaction with Beclin 1. HeLa cells were cotransfected with GFP-LC3 and three $\mathrm{IP}_{3} \mathrm{R}$-LBD-RFP chimeric proteins targeted to different subcellular compartments, namely the cytosol (Cyto), the outer mitochondrial membrane (OMM) and the endoplasmic reticulum (ER). An inactive ER-targeted IP ${ }_{3}^{R}$-LBD-RFP, including a non-apeptide linker (9aaER) as well as equally targeted variants of RFP alone were used as controls. Twenty-four hours after transfection, cells were subjected to treatment with xestospongin B or nutrient starvation. Representative pictures of Hoechst 33342counterstained cells were taken $4 \mathrm{~h}$ after treatment (a) and the percentage of adherent cells exhibiting GFP-LC3 vacuolization into cytoplasmic puncta was determined (b). The interaction between the $\mathrm{IP}_{3} \mathrm{R}$-LBD and Beclin 1 was assessed by immunoprecipitation experiments in HeLa cells that were transiently expressing IP ${ }_{3} R$-LBD-ER-RFP and concomitantly subjected to siRNA-mediated emerin or Bcl-2 knockdown as indicated (c). Coimmunoprecipitated Beclin 1 levels were normalized relative to input protein levels (d). LC3-II levels from the input lysates were normalized relative to GAPDH levels (e). Data are reported as mean \pm S.E.M. of three independent experiments carried out in triplicates. ${ }^{*} P<0.05$ and ${ }^{* *} P<0.01$. The colour reproduction of this figure is available on the html full version of the manuscript 
Wetzlar, Germany). Confocal microscopy was carried out with a Leica TSC-SPE microscope equipped with a $63 \times / 1.15$ Olympus objective by using LAS software (Leica Microsystems). Cells presenting a diffuse distribution of GFP-LC3 in the cytoplasm and nucleus were considered as non-autophagic, whereas cells exhibiting both several intense punctuate GFP-LC3 aggregates and nuclear GFPLC3 exclusion were classified as autophagic (GFP-LC3 ${ }^{\text {vac }}$ ). Each GFP-LC3 staining was independently quantified by two investigators (JMV and CO).

Measurement of intracellular $\mathbf{I P}_{\mathbf{3}}$ levels. HeLa cells $\left(4 \times 10^{6}\right)$ were seeded in $100 \mathrm{~mm}$ culture dishes and were incubated after $24 \mathrm{~h}$ with L-690 330 $(100 \mu \mathrm{M})$, myo-inositol $(10 \mu \mathrm{M})$ and/or xestospongin $\mathrm{B}(2 \mu \mathrm{M})$ for $0-100 \mathrm{~min}$. Immediately afterwards, they were stimulated with histamine $(100 \mu \mathrm{M})$ for $0-3 \mathrm{~min}$ and lysed with $0.2 \mathrm{M}$ ice-cold trichloroacetic acid. Cell extracts were then subjected to a radioreceptor assay (Perkin Elmer no. NEK064, Waltham, MA, USA). IP levels were quantified in a liquid scintillation counter (Packard Tri-carb 2100TR, Packard Instrument, Meriden, CT, USA) and normalized to the amount of protein contained in each sample. Results are presented as mean \pm S.E.M. Three independent experiments were carried out in triplicate and statistical significance was evaluated by Student's $t$-test.

Plasmids, transfection and RNA interference. Cells were cultured in 6-well plates and transfected at $80 \%$ confluence by using Oligofectamine reagent (Invitrogen), with small interfering RNAs (siRNAs) specifically targeting human Beclin 1 (sense $5^{\prime}$-GAUUGAAGACACAGGAGGC-3), ${ }^{47,48}$ Bcl-2 (sense $5^{\prime}$-GCUGCACCUGACGCCCUUCTT-3' $)^{47,49}$ or the unrelated protein emerin (sense $5^{\prime}$-TATGTCCTCCTCATCATCTTCCT- $3^{\prime}$ ). ${ }^{50}$ All siRNAs were purchased from Sigma-Proligo. Transient transfections with plasmids were carried out with Lipofectamine 2000 reagent (Invitrogen) and cells were used $24 \mathrm{~h}$ after transfection. Cells were transfected with an empty control vector or with a plasmid encoding for GFP-LC3. ${ }^{51}$ Cotransfection was carried out using a mixture of the GFP-LC3encoding plasmid and plasmids encoding for variants of the $\mathrm{P}_{3} \mathrm{R}$-LBD coupled to RFP targeted to different subcellular compartments, namely the cytosol (IP ${ }_{3} \mathrm{R}-\mathrm{LBD}$ RFP-Cyto), the OMM ( $\mathbb{P}_{3} R$-LBD-RFP-OMM) and the ER ( P $_{3} R$-LBD-RFP-ER). As controls, a plasmid coding for an ER-targeted $I P_{3} R$-LBD that is rendered inactive by the incorporation of a nonapeptide linker sequence (IP ${ }_{3} R$-9aa-LBD-RFP-ER), as well as plasmids encoding RFP alone targeted to the cytosol (RFP-Cyto), the OMM (RFP-OMM) or the ER (RFP-ER) were used. ${ }^{24,37,52}$

Acknowledgements. GK is supported by the Ligue Nationale contre le Cancer (équipe labellisée), European Commission (RIGHT, ChemoRes, ApopTrain, Apo-SYs), Agence Nationale pour la Recherche, Cancéropôle lle-de-France and Institut National contre le Cancer (INCa). We thank the International Collaboration Program ECOS-CONICYT, project C08S01. JMV is supported by Fondation pour la Recherche Médicale and CONICYT. CO holds a PhD scholarship from CONICYT, Chile. OK is supported by EMBO. AWEJ is a Medical Research Council student. We also thank Michael R Duchen (University College London) for the use of confocal facility (Zeiss LSM 510 Meta) and discussions, as well as to Dr. Roger Y Tsien (University of California at San Diego) for the donation of ERD1.

1. Klionsky DJ. Autophagy: from phenomenology to molecular understanding in less than a decade. Nat Rev Mol Cell Biol 2007; 8: 931-937.

2. Klionsky DJ, Emr SD. Autophagy as a regulated pathway of cellular degradation. Science 2000; 290: 1717-1721.

3. Yorimitsu T, Klionsky DJ. Autophagy: molecular machinery for self-eating. Cell Death Differ 2005; 12 (Suppl 2): 1542-1552.

4. Rubinsztein DC, Gestwicki JE, Murphy LO, Klionsky DJ. Potential therapeutic applications of autophagy. Nat Rev Drug Discov 2007; 6: 304-312.

5. Klionsky DJ, Cregg JM, Dunn Jr WA, Emr SD, Sakai Y, Sandoval IV et al. A unified nomenclature for yeast autophagy-related genes. Dev Cell 2003; 5: 539-545.

6. Xie Z, Klionsky DJ. Autophagosome formation: core machinery and adaptations. Nat Cell Biol 2007; 9: 1102-1109.

7. Aita VM, Liang XH, Murty VV, Pincus DL, Yu W, Cayanis E et al. Cloning and genomic organization of beclin 1, a candidate tumor suppressor gene on chromosome 17q21. Genomics 1999; 59: 59-65.

8. Yue Z, Jin S, Yang C, Levine AJ, Heintz N. Beclin 1, an autophagy gene essential for early embryonic development, is a haploinsufficient tumor suppressor. Proc Natl Acad Sci USA 2003; 100: 15077-15082.

9. Galluzzi L, Vicencio JM, Kepp O, Tasdemir E, Maiuri MC, Kroemer G. To die or not to die: that is the autophagic question. Curr Mol Med 2008; 8: 78-91.
10. Galluzzi L, Maiuri MC, Vitale I, Zischka H, Castedo M, Zitvogel L et al. Cell death modalities: classification and pathophysiological implications. Cell Death Differ 2007; 14: 1237-1243.

11. Kroemer G, Galluzzi L, Vandenabeele P, Abrams J, Alnemri ES, Baehrecke EH et al. Classification of cell death: recommendations of the Nomenclature Committee on Cell Death 2009. Cell Death Differ 2009; 16: 3-11.

12. Levine B, Sinha S, Kroemer G. Bcl-2 family members: dual regulators of apoptosis and autophagy. Autophagy 2008; 4: 600-606.

13. Maiuri MC, Zalckvar E, Kimchi A, Kroemer G. Self-eating and self-killing: crosstalk between autophagy and apoptosis. Nat Rev Mol Cell Biol 2007; 8: 741-752.

14. Pattingre S, Tassa A, Qu X, Garuti R, Liang XH, Mizushima N et al. Bcl-2 antiapoptotic proteins inhibit Beclin 1-dependent autophagy. Cell 2005; 122: 927-939.

15. Maiuri MC, Le Toumelin G, Criollo A, Rain JC, Gautier F, Juin P et al. Functional and physical interaction between $\mathrm{Bcl}-\mathrm{X}(\mathrm{L})$ and a BH3-like domain in Beclin-1. EMBO J 2007; 26: 2527-2539.

16. Wei Y, Pattingre S, Sinha S, Bassik M, Levine B. JNK1-mediated phosphorylation of Bcl-2 regulates starvation-induced autophagy. Mol Cell 2008; 30: 678-688.

17. Sarkar S, Floto RA, Berger Z, Imarisio S, Cordenier A, Pasco M et al. Lithium induces autophagy by inhibiting inositol monophosphatase. J Cell Biol 2005; 170: 1101-1111.

18. Williams A, Sarkar S, Cuddon P, Ttofi EK, Saiki S, Siddiqi FH et al. Novel targets for Huntington's disease in an mTOR-independent autophagy pathway. Nat Chem Biol 2008; 4: 295-305.

19. Gordon PB, Holen I, Fosse M, Rotnes JS, Seglen PO. Dependence of hepatocytic autophagy on intracellularly sequestered calcium. J Biol Chem 1993; 268: 26107-26112.

20. Brady NR, Hamacher-Brady A, Yuan H, Gottlieb RA. The autophagic response to nutrient deprivation in the $\mathrm{hl}-1$ cardiac myocyte is modulated by $\mathrm{Bcl}-2$ and sarco/endoplasmic reticulum calcium stores. FEBS J 2007; 274: 3184-3197.

21. Gao W, Ding WX, Stolz DB, Yin XM. Induction of macroautophagy by exogenously introduced calcium. Autophagy 2008; 4: 754-761.

22. Hoyer-Hansen M, Bastholm L, Szyniarowski P, Campanella M, Szabadkai G, Farkas $T$ et al. Control of macroautophagy by calcium, calmodulin-dependent kinase kinase-beta, and Bcl-2. Mol Cell 2007; 25: 193-205.

23. Berridge MJ, Bootman MD, Roderick HL. Calcium signalling: dynamics, homeostasis and remodelling. Nat Rev Mol Cell Biol 2003; 4: 517-529.

24. Szabadkai G, Bianchi K, Varnai P, De Stefani D, Wieckowski MR, Cavagna D et al Chaperone-mediated coupling of endoplasmic reticulum and mitochondrial $\mathrm{Ca} 2+$ channels. J Cell Biol 2006; 175: 901-911.

25. Szabadkai G, Rizzuto R. Participation of endoplasmic reticulum and mitochondrial calcium handling in apoptosis: more than just neighborhood? FEBS Lett 2004; 567: 111-115.

26. Berridge MJ. The endoplasmic reticulum: a multifunctional signaling organelle. Cell Calcium 2002; 32: 235-249

27. Rong $\mathrm{Y}$, Distelhorst $\mathrm{CW}$. Bcl-2 protein family members: versatile regulators of calcium signaling in cell survival and apoptosis. Annu Rev Physiol 2008; 70: 73-91.

28. Kroemer G, Galluzzi L, Brenner C. Mitochondrial membrane permeabilization in cell death. Physiol Rev 2007; 87: 99-163.

29. Criollo A, Maiuri MC, Tasdemir E, Vitale I, Fiebig AA, Andrews D et al. Regulation of autophagy by the inositol trisphosphate receptor. Cell Death Differ 2007; 14: 1029-1039.

30. Criollo A, Vicencio JM, Tasdemir E, Maiuri MC, Lavandero S, Kroemer G. The inosito trisphosphate receptor in the control of autophagy. Autophagy 2007; 3: 350-353.

31. Lam D, Golstein P. A specific pathway inducing autophagic cell death is marked by an IP3R mutation. Autophagy 2008; 4: 349-350.

32. Lam D, Kosta A, Luciani MF, Golstein P. The Inositol 1,4,5-Trisphosphate Receptor Is Required to Signal Autophagic Cell Death. Mol Biol Cell 2008; 19: 691-700.

33. Klionsky DJ, Abeliovich H, Agostinis P, Agrawal DK, Aliev G, Askew DS et al. Guidelines for the use and interpretation of assays for monitoring autophagy in higher eukaryotes. Autophagy 2008; 4: 151-175.

34. Mizushima N, Yoshimori T. How to interpret LC3 immunoblotting. Autophagy 2007; 3 $542-545$.

35. Mikoshiba K. IP3 receptor/Ca2+ channel: from discovery to new signaling concepts. $J$ Neurochem 2007; 102: 1426-1446

36. Mikoshiba K. The IP3 receptor/Ca2+ channel and its cellular function. Biochem Soc Symp 2007: 74: 9-22.

37. Varnai $P$, Balla A, Hunyady L, Balla T. Targeted expression of the inositol 1,4,5triphosphate receptor (IP3R) ligand-binding domain releases $\mathrm{Ca} 2+$ via endogenous IP3R channels. Proc Natl Acad Sci USA 2005; 102: 7859-7864.

38. Jaimovich E, Mattei $\mathrm{C}$, Liberona JL, Cardenas $\mathrm{C}$, Estrada M, Barbier J et al. Xestospongin $\mathrm{B}$, a competitive inhibitor of IP3-mediated $\mathrm{Ca} 2+$ signalling in cultured rat myotubes, isolated myonuclei, and neuroblastoma (NG108-15) cells. FEBS Lett 2005; 579: 2051-2057.

39. Gafni J, Munsch JA, Lam TH, Catlin MC, Costa LG, Molinski TF et al. Xestospongins: potent membrane permeable blockers of the inositol 1,4,5-trisphosphate receptor. Neuron 1997; 19: 723-733.

40. Guillemette J, Caron AZ, Regimbald-Dumas Y, Arguin G, Mignery GA, Boulay G et al Expression of a truncated form of inositol 1,4,5-trisphosphate receptor type III in the cytoso of DT40 triple inositol 1,4,5-trisphosphate receptor-knockout cells. Cell Calcium 2005; 37 97-104.

41. Devogelaere B, Verbert L, Parys JB, Missiaen L, De Smedt H. The complex regulatory function of the ligand-binding domain of the inositol 1,4,5-trisphosphate receptor. Cell Calcium 2008; 43: 17-27. 
42. Quirion JC, Sevenet $T$, Husson HP, Weniger B, Debitus $C$. Two new alkaloids from Xestospongia sp., a New Caledonian sponge. J Nat Prod 1992; 55: 1505-1508.

43. Grynkiewicz G, Poenie M, Tsien RY. A new generation of Ca2+ indicators with greatly improved fluorescence properties. J Biol Chem 1985; 260: 3440-3450.

44. Chiesa A, Rapizzi E, Tosello V, Pinton P, de Virgilio M, Fogarty KE et al. Recombinan aequorin and green fluorescent protein as valuable tools in the study of cell signalling. Biochem J 2001; 355: 1-12.

45. Palmer AE, Jin C, Reed JC, Tsien RY. Bcl-2-mediated alterations in endoplasmic reticulum $\mathrm{Ca} 2+$ analyzed with an improved genetically encoded fluorescent sensor. Proc Natl Acad Sci USA 2004; 101: 17404-17409.

46. Gonzalez-Polo RA, Boya P, Pauleau AL, Jalil A, Larochette N, Souquere $\mathrm{S}$ et al. The apoptosis/autophagy paradox: autophagic vacuolization before apoptotic death. J Cell Sci 2005; 118: 3091-3102.
47. Criollo A, Galluzzi L, Maiuri MC, Tasdemir E, Lavandero S, Kroemer G. Mitochondrial control of cell death induced by hyperosmotic stress. Apoptosis 2007; 12: 3-18.

48. Boya P, Gonzalez-Polo RA, Casares N, Perfettini JL, Dessen P, Larochette N et al. Inhibition of macroautophagy triggers apoptosis. Mol Cell Biol 2005; 25: 1025-1040.

49. Jiang M, Milner J. Bcl-2 constitutively suppresses p53-dependent apoptosis in colorectal cancer cells. Genes Dev 2003; 17: 832-837.

50. Harborth J, Elbashir SM, Bechert K, Tuschl T, Weber K. Identification of essential genes in cultured mammalian cells using small interfering RNAs. J Cell Sci 2001; 114: 4557-4565.

51. Kabeya Y, Mizushima N, Ueno T, Yamamoto A, Kirisako T, Noda T et al. LC3, a mammalian homologue of yeast Apg8p, is localized in autophagosome membranes after processing. EMBO J 2000; 19: 5720-5728.

52. Lin X, Varnai P, Csordas G, Balla A, Nagai T, Miyawaki A et al. Control of calcium signal propagation to the mitochondria by inositol 1,4,5-trisphosphate-binding proteins. J Biol Chem 2005; 280: 12820-12832.

Supplementary Information accompanies the paper on Cell Death and Differentiation website (http://www.nature.com/cdd) 